\title{
The Urochloa Foliar Blight and Collar Rot Pathogen Rhizoctonia solani AG-1 IA Emerged in South America Via a Host Shift from Rice
}

\author{
Edisson Chavarro Mesa, Paulo C. Ceresini, Lina M. Ramos Molina, Danilo A. S. Pereira, Daniel A. Schurt, \\ José R. Vieira Jr., Nadia M. Poloni, and Bruce A. McDonald
}

First and third authors: UNESP University of São Paulo State, Jaboticabal Campus, SP, Brazil; second, fourth, and seventh authors: UNESP, Ilha Solteira Campus, SP, Brazil; fifth author: EMBRAPA Brazilian Agricultural Research Corporation, Boa Vista, RR, Brazil; sixth author: EMBRAPA, Porto Velho, RO, Brazil; and eighth author: Institute of Integrative Biology, ETH Zurich, Switzerland.

Accepted for publication 9 July 2015.

\begin{abstract}
Chavarro Mesa, E., Ceresini, P. C., Ramos Molina, L. M., Pereira, D. A. S., Schurt, D. A., Vieira, J. R., Jr., Poloni, N. M., and McDonald, B. A. 2015. The Urochloa foliar blight and collar rot pathogen Rhizoctonia solani AG-1 IA emerged in South America via a host shift from rice. Phytopathology 105:1475-1486.

The fungus Rhizoctonia solani anastomosis group (AG)-1 IA emerged in the early 1990s as an important pathogen causing foliar blight and collar rot on pastures of the genus Urochloa (signalgrass) in South America. We tested the hypothesis that this pathogen emerged following a host shift or jump as a result of geographical overlapping of host species. The genetic structure of host and regional populations of $R$. solani AG-1 IA infecting signalgrass, rice, and soybean in Colombia and Brazil was analyzed using nine microsatellite loci in 350 isolates to measure

Phylogeographical analyses based on the microsatellite loci and on three DNA sequence loci were used to infer historical migration patterns and test hypotheses about the origin of the current pathogen populations. Cross pathogenicity assays were conducted to measure the degree of host specialization in populations sampled from different hosts. The combined analyses indicate that the pathogen populations currently infecting Urochloa in Colombia and Brazil most likely originated from a population that originally infected rice. $R$. solani AG-1 IA populations infecting Urochloa exhibit a mixed reproductive system including both sexual reproduction and long-distance dispersal of adapted clones, most likely on infected seed. The pathogen population on Urochloa has a genetic structure consistent with a high evolutionary potential and showed evidence for host specialization.
\end{abstract} population differentiation and infer the pathogen reproductive system.

Rhizoctonia solani anastomosis group (AG)-1 IA is an important fungal pathogen with a worldwide distribution that affects a wide range of host crops (Jones and Belmar 1989; Pascual et al. 2000). In South America, AG-1 IA causes sheath blight on rice (Oryza sativa L.) (Bolkan and Ribeiro 1985; Cedeño et al. 1996; Costa-Souza et al. 2007), banded leaf and sheath spot on maize (Zea mays L.) (Cardona et al. 1999), leaf or aerial blight on soybeans (Glycine max (L.) Merrill) (Ciampi et al. 2008), and web blight on cowpea (Vigna unguiculata (L.) Walp.) (Nechet and Halfeld-Vieira 2007). Although $R$. solani AG-1 IA is associated with a wide range of hosts, recent studies indicated that sympatric populations infecting Poaceae or Fabaceae represent two phylogenetically well-defined sister groups and that selection for host specialization likely resulted in divergence between the populations (Bernardes de Assis et al. 2008; Ciampi et al. 2005). In general, $R$. solani AG-1 IA survives as mycelia and sclerotia in soil, with repeated infection cycles increasing the inoculum level in soil (Ogoshi 1987). The pathogen is known to be transmitted among fields on infested plants, seeds, or equipment, but weeds may also play an important role in disseminating the fungus among different crops (Black et al. 1996).

$R$. solani AG-1 IA emerged in the early 1990s as an important pathogen causing foliar blight, collar rot, and death of Urochloa

Corresponding author: P. C. Ceresini;

E-mail address: paulo.ceresini@bio.feis.unesp.br

The first, second, and third authors contributed equally to this manuscript.

*The $\boldsymbol{e}$-Xtra logo stands for "electronic extra" and indicates that one supplementary table is published online.

http://dx.doi.org/10.1094/PHYTO-04-15-0093-R

(C) 2015 The American Phytopathological Society
Additional keywords: gene flow, pathogen emergence, pathogen origins. (formerly classified as Brachiaria [Torres González and Morton 2005] and also called signalgrass) pastures in South America (CIAT 1993). In Colombia the fungus first emerged in areas where rice, a host highly susceptible to the fungus (Hashiba and Kobayashi 1996; Lee and Rush 1983), was replaced by Urochloa in response to a growing demand for extensive livestock farming. Urochloa is an important forage grass in tropical Latin America, where it is cultivated on approximately 160 million hectares in Brazil alone (IBGE 2006). $R$. solani AG-1 IA was first described as an Urochloa pathogen in Brazil in 1999 (Verzignassi and Fernandes 2001) but was only recently reported as an important forage grass pathogen (Marchi et al. 2011). It specifically attacks $U$. brizantha 'Marandu' in the states of Acre, Maranhão, Northern Mato Grosso, Rondônia, Southern Pará, and Tocantins, all located in the Amazon region (Duarte et al. 2007; Valle et al. 2000; Verzignassi and Fernandes 2001). Extensive damage on Urochloa was reported in both Brazil and Colombia (Argel et al. 2005; Duarte et al. 2007). Economical losses caused by Rhizoctonia foliar blight on Urochloa were not quantified to date (Alvarez et al. 2013; Marchi et al. 2011). However, during periods of high relative humidity and temperatures, Rhizoctonia foliar blight is considered devastating in tropical Latin America Urochloa monocultures. The disease is characterized by extensive foliage necrosis that evolves to patches of scorched tillers reducing the stands of the pasture (Alvarez et al. 2013; Argel et al. 2005; Marchi et al. 2011).

Early reports indicated that Urochloa hosts two different $R$. solani AGs: AG-1 IA and AG-1 IB (Black et al. 1996). Both AG-1 IA and AG-1 IB produce abundant sclerotia in infected tissue. However, AG-1 IA produces larger sasakii-type sclerotia that are between 1 and $6 \mathrm{~mm}$ in diameter and are generally not air-dispersed (Yang et al. 1989). In contrast, AG-1 IB produces microsclerotia, allowing the pathogen to be air-dispersed (Galindo et al. 1983; Weber 1939). 
In the first study describing the reaction of Urochloa species to the foliar blight disease in Colombia (Kelemu et al. 1995), $R$. solani AG-1 IA was likely used as inoculum because the isolate produced large sclerotia of the sasakii-type. Recent reports indicated that $R$. solani AG-1 IA was prevalent in Urochloa pastures from Colombia warm lowland areas ( $\sim 69 \%$ of the samples), while Rhizoctonia sp. AG-D (Ceratobasidium sp.) was detected only in the cooler areas of Cauca department ( $\sim 31 \%$ of the samples) (Alvarez et al. 2013). Existing reports describing the occurrence of $R$. solani in Amazon pastures in Brazil do not specify which AGs were associated with Urochloa (Duarte et al. 2007; Verzignassi and Fernandes 2001). Recently, Gaino et al. (2010) reported the association of AG-4 HGI causing collar rot of Urochloa in Paragominas in Pará state. However, a broad survey performed by our group indicated that $R$. solani AG-1 IA was the sole pathogen responsible for Urochloa foliar blight in the Colombian Llanos (Chavarro Mesa et al. 2012) and in the Brazilian Amazon, especially in Rondônia (Chavarro Mesa et al. 2014).

The two main Urochloa species grown in Brazilian pasture agroecosystems, $U$. brizantha and $U$. decumbens, in addition to forming extensive monocultures, are composed of apomictic ecotypes (Dall'Agnol and Schifino-Wittmann 2005). Hence, these grasses reproduce mainly asexually, resulting in low genetic diversity in the established pasture populations. This genetic uniformity increases the risk of emergence of new pests and/or diseases (Stukenbrock and McDonald 2008) and may result in the loss of highly susceptible varieties, as reported for $U$. decumbens in the Amazon region (Seiffert 1984). There are no conclusive indications in historical or scientific reports that the pattern of emergence of $R$. solani as a pathogen of Urochloa pastures in Brazil is similar to the pattern observed in Colombia, where $R$. solani emerged in areas where rice was previously cultivated. However, the emergence of $R$. solani as an Urochloa pathogen may also have resulted from pasture expansion into adjacent areas or into areas previously cultivated with pathogen-susceptible hosts such as rice, cowpea, and soybean (Costa-Souza et al. 2007; Nechet and Halfeld-Vieira 2007).

In the present study, the following questions were addressed: What is the genetic relationship among pathogen populations adapted to signalgrass, rice, and soybean in Colombia and Brazil? Are the $R$. solani AG-1 IA populations adapted to signalgrass, rice, or soybean genetically differentiated? What is the origin of the $R$. solani AG-1 IA populations adapted to signalgrass? To answer these questions we aimed to determine the levels of historical migration and contemporary gene flow between sympatric pathogen populations adapted to signalgrass and those adapted to rice or soybean from the same geographical region. We analyzed genetic diversity within and among field populations using nine microsatellite markers to identify migration patterns, determine the origins of Urochloaadapted populations, and clarify the main reproductive system of $R$. solani AG-1 IA in each region. We also sought evidence regarding the origin of the Urochloa-adapted populations of $R$. solani AG-1 IA using coalescent analyses coupled with ancestral reconstruction and discrete phylogeography based on three nuclear DNA loci.

\section{MATERIALS AND METHODS}

Pathogen population samples. Population samples of $R$. solani AG-1 IA were collected between 2010 and 2013. A total of 204 fungal isolates were obtained from the Llanos region of northeast Colombia. Three sympatric field populations of $R$. solani AG-1 IA were sampled from the State of Meta: one infecting $U$. brizantha 'Toledo' (COL_BBT), one infecting the Urochloa hybrid Mulato (COL_BHM), and one infecting rice (COL_OS) (Fig. 1; Table 1). In Brazil, a total of 146 fungal isolates were obtained by sampling three different locations in Rondônia state. Four sympatric field populations were collected in Alto Paraíso, Nova União, and Itapuã d'Oeste counties: one infecting soybean (population RO_S) and three infecting $U$. brizantha 'Marandu' (RO_B1, RO_B2, and RO_B3).
One allopatric population was sampled from rice in Roraima state (RR_R) (Fig. 1; Table 1).

Samples of infected plants showing symptoms of Urochloa foliar blight, rice sheath blight, or soybean aerial blight were collected from six to eight disease foci per row ( $\sim 10 \mathrm{~m}$ between each focus $)$ in a total of five rows per field and keeping a single isolate per focus, with the goal of obtaining approximately 30 to 40 isolates per field population. Isolation and preservation of the fungal isolates were performed as previously described (Ciampi et al. 2008). Briefly, isolations were made by placing fragments of infected leaves into Petri dishes containing modified Ko and Hora selective medium (Ko and Hora 1971) and incubating at $25^{\circ} \mathrm{C}$ in the dark. Pure cultures were established by transferring hyphal fragments to potato dextrose agar medium containing chloramphenicol and streptomycin at $50 \mu \mathrm{g} / \mathrm{ml}$. Sclerotia from 5-day-old cultures were transferred to 1.8 -ml cryotubes containing anhydrous silica gel for long-term storage at $-20^{\circ} \mathrm{C}$ (Ciampi et al. 2008).

DNA extraction and genotyping. Fungal mycelium was grown in $30 \mathrm{ml}$ of potato dextrose broth ( $18.5 \mathrm{~g} / \mathrm{liter})$ for 4 days on a shaker at $70 \mathrm{rpm}$, after which the mycelium was collected by filtration and freeze-dried for approximately $48 \mathrm{~h}$. DNA was extracted using the GenElute kit (Sigma-Aldrich) according to the manufacturer's instructions. The anastomosis group of each isolate was determined through selective amplification of a fragment of the fungal $28 \mathrm{~S}$ ribosomal DNA (rDNA) by polymerase chain reaction (PCR) using specific primers, including the $R$. solani AG universal primer (forward) $5^{\prime}$-CTCAAACAGGCATGCTC-3', and the $R$. solani AG-1 IA specific primer (reverse) 5'-CAGCAATAGTTGGTGGA-3' (Ciampi et al. 2008; Matsumoto 2002).

$R$. solani AG-1 IA isolates were genotyped using nine codominant microsatellite (SSR) markers (Zala et al. 2008). All forward primers were designed to contain a 5'-TGTAAAACGACGGCCAGT-3' (M13F) tail. Each SSR primer was labeled with a fluorescent dye by adding to the PCR an extra primer containing a sequence similar to the M13F primer that was labeled with one of the following fluorophores: 6-FAM, NED, VIC, or PET (Life Technologies) (Schuelke 2000). The PCR reactions were performed separately for each SSR locus in $20 \mu \mathrm{l}$ final volume. Each reaction contained approximately $5 \mu \mathrm{l}$ of genomic DNA (final concentration between 5 and $15 \mathrm{ng} / \mu \mathrm{l}), 2 \mu \mathrm{l}$ of $10 \times$ buffer, $0.4 \mathrm{mM}$ dNTPs, $0.3 \mu \mathrm{M}$ of each primer, $0.5 \mu \mathrm{M}$ of fluorophore-labeled M13F, and 1 unit of Taq polymerase (Sigma-Aldrich). For all sets of primers, the PCR program included an initial denaturation step at $94^{\circ} \mathrm{C}$ for $3 \mathrm{~min}$ followed by 30 cycles of denaturation at $95^{\circ} \mathrm{C}$ for $35 \mathrm{~s}$, annealing at $55^{\circ} \mathrm{C}$ for $30 \mathrm{~s}$ and extension at $72^{\circ} \mathrm{C}$ for $40 \mathrm{~s}$ and a final extension step at $72^{\circ} \mathrm{C}$ for $8 \mathrm{~min}$. Fragment analysis of the amplified PCR products was performed by Macrogen, South Korea, using an ABI 3700 capillary sequencer (Applied Biosystems) and GeneScan $500 \mathrm{Liz}$ as an internal size standard (Applied Biosystems) according to the manufacturer's instructions. Seven control isolates carrying representative common alleles were included in every run of 91 samples as additional size standards. The binning of alleles into fragment size categories consistent with the respective unit increment described by Zala et al. (2008) was implemented using the program Geneious (http://www. geneious.com, Biomatters, Auckland, Nova Zelândia).

Analyses of population genetic structure. For all analyses, $R$. solani AG-1 IA was assumed to be a heterokaryon or functional diploid. The multilocus SSR genotype for each isolate was determined using GenoDive (Meirmans and Van Tienderen 2004). Isolates with the same multilocus SSR genotype were considered members of the same clonal lineage. The following indices of genotypic diversity were determined: (i) number of multilocus genotypes per population; (ii) population-specific genotypes; and (iii) clonal fraction, calculated as 1 - (number of different genotypes)/(total number of isolates); (iv) $G_{O}$, the effective number of genotypes, and their (v) evenness (Zhan et al. 2003). The statistical significance of differences in genotypic diversity between each pair of field populations was tested using bootstrap resampling with 1,000 permutations, with subsampling to 
match the size of the smallest field population (20 individuals). Individuals from each population were resampled, and diversity indices were calculated and compared following each run (Meirmans and Van Tienderen 2004).

Clone-corrected datasets were used for all remaining analyses, retaining one unique individual of each multilocus genotype per population. Allelic richness was estimated as the average number of alleles per locus using rarefaction (El Mousadik and Petit 1996). Differences in allelic richness between groups of populations were tested using FSTAT 2.9.3.2 (Goudet 1995). $P$ values for the significance of differences between pairs of means were obtained with 1,000 permutations.

The degree of population subdivision and the distribution of gene diversity between sympatric host populations and allopatric regional populations was determined using hierarchical analysis of molecular variance (AMOVA) (Excoffier et al. 2005). The AMOVA was performed by subdividing the variance components into variance between populations, variance within populations and variance within individuals. The significance of the fixation index $\left(R_{S T}\right.$, based on the squared size differences between alleles for SSR microsatellite loci)

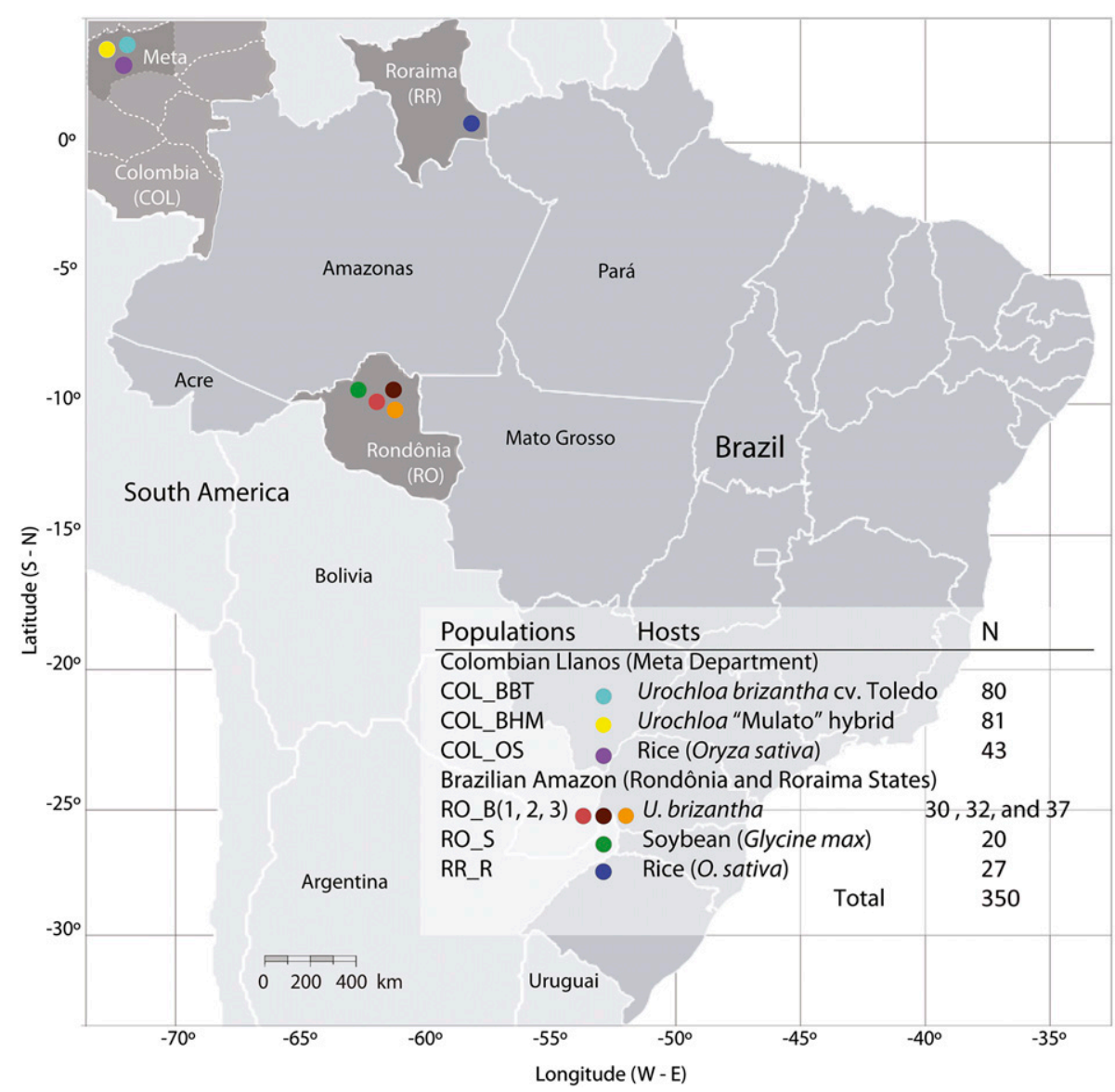

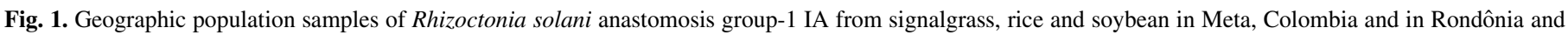
Roraima, Brazil. The latitude (north-south) and longitude (west-east) values are indicated on the map.

TABLE 1. Sympatric populations of Rhizoctonia solani anastomosis group-1 IA from signalgrass, rice, and soybean sampled at Meta, Colombia and at Rondônia and Roraima, Brazil

\begin{tabular}{|c|c|c|c|c|c|c|}
\hline Countries, states and counties & District & Isolates $N^{z}$ & Population & Coordinates & Host & Year of collection \\
\hline \multicolumn{7}{|l|}{ Colombia } \\
\hline \multicolumn{7}{|l|}{ Meta } \\
\hline Puerto López & Puerto López & 80 & COL_BBT & $4^{\circ} 07^{\prime} 13.40^{\prime \prime} \mathrm{N}, 72^{\circ} 49^{\prime} 52.99^{\prime \prime} \mathrm{W}$ & Urochloa brizantha 'Toledo' & 2010 \\
\hline Puerto López & La Bonga & 81 & COL_BHM & $4^{\circ} 13^{\prime} 35.45^{\prime \prime} \mathrm{N}, 72^{\circ} 28^{\prime} 58.36^{\prime \prime} \mathrm{W}$ & Urochloa hybrid Mulato & 2010 \\
\hline Villavicencio & La Libertad & & & $4^{\circ} 03^{\prime} 25.17^{\prime \prime} \mathrm{N}, 73^{\circ} 27^{\prime} 45.38^{\prime \prime} \mathrm{W}$ & Urochloa hybrid Mulato & 2010 \\
\hline Villavicencio & Pompeya & 43 & COL_OS & $4^{\circ} 02^{\prime} 26.64^{\prime \prime} \mathrm{N}, 73^{\circ} 21^{\prime} 15.76^{\prime \prime} \mathrm{W}$ & Rice 'Thailandia' & 2011 \\
\hline \multicolumn{7}{|l|}{ Brazil } \\
\hline Alto Paraíso & & 30 & RO_B1 & $9^{\circ} 29.205^{\prime} \mathrm{S}, 63^{\circ} 23.948^{\prime} \mathrm{W}$ & U. brizantha 'Marandú' & 2013 \\
\hline & & 32 & RO_B2 & $9^{\circ} 50.486^{\prime} \mathrm{S}, 63^{\circ} 39.661^{\prime} \mathrm{W}$ & U. brizantha 'Marandú' & 2013 \\
\hline Nova União & & 37 & RO_B3 & $\begin{array}{l}10^{\circ} 42.506^{\prime} \mathrm{S}, 62^{\circ} 27.340^{\prime} \mathrm{W} \\
10^{\circ} 41.163^{\prime} \mathrm{S}, 62^{\circ} 28.831^{\prime} \mathrm{W}\end{array}$ & U. brizantha 'Marandú' & 2013 \\
\hline Roraima (RR) & & & & & & \\
\hline Boa Vista & & 27 & RR_R & $2^{\circ} 48.718^{\prime} \mathrm{S}, 60^{\circ} 39.073^{\prime} \mathrm{W}$ & Rice, unknown variety & 2013 \\
\hline
\end{tabular}

${ }^{\mathrm{z}} N=$ sample size (number of isolates) of each population. 
was tested using a nonparametric approach with 1,000 permutations using ARLEQUIN 3.11 (Excoffier et al. 2005). Differentiation between populations was determined by calculating the pairwise fixation indices $\left(\Phi_{S T}\right.$, analogous to $\left.R_{S T}\right)$. A null $\Phi_{S T}$ distribution, under the hypothesis of no differentiation between two populations, was obtained by haplotype permutation between population pairs using ARLEQUIN 3.11. Genetic differentiation between population pairs was considered significant at $P<0.05$.

Tests for Hardy-Weinberg equilibrium, gametic disequilibrium, and admixture. To assess the contribution of recombination to the genetic structure of the populations, associations within and between loci were investigated using the Hardy-Weinberg equilibrium (HWE) and multilocus association tests, respectively. HWE $P$ values were obtained with ARLEQUIN 3.11 using the Markov chain Monte Carlo (MCMC) method that generates an exact probability distribution not biased by rare alleles or small sample size (Excoffier et al. 2005). The mean inbreeding coefficient $\left(F_{\text {IS }}\right)$ across all loci was calculated for each population (Excoffier et al. 2005) in ARLEQUIN 3.11 to test for significant heterozygote deficit or excess relative to HWE predictions using 1,000 permutations. Associations between loci were examined using two tests for gametic disequilibrium. The first test was the proportion of pairs of loci in disequilibrium using Fisher's exact test based on the MCMC algorithm, with 1,000 randomizations conducted in GENEPOP 3.4 (Raymond and Rousset 1995). A pair of loci was considered to be in disequilibrium when the $P$ values were equal to or less than 0.05 following Bonferroni's correction. The second test used the multilocus association index $\left(r_{D}\right)$ for each population (Maynard Smith et al. 1993), corrected for the total number of loci. The significance of $r_{D}$ values was tested with 1,000 randomizations using both MULTILOCUS 1.3 (Agapow and Burt 2001) and the poppr 1.0.5 R package (Kamvar et al. 2014). The null hypothesis of complete panmixia, i.e., no associations between pairs of loci, was tested within each population.

Deviations from HWE and gametic disequilibrium observed in some populations could be caused by the Wahlund effect, reflecting genotype admixture among populations. STRUCTURE v.2.2 was used (Pritchard et al. 2000) to determine whether any sampled individuals were immigrants relative to their reference geographical populations. Ten runs with 100,000 generations burn in and simulations with 1,000,000 MCMC iterations for each run were performed. The membership coefficient for each sampled genotype was determined by setting each of the eight reference geographical or host populations as a potential population of origin for each

TABLE 2. Measures of genotypic and gene diversity in sympatric populations of Rhizoctonia solani anastomosis group-1 IA from signalgrass, rice, and soybean from Meta, Colombia and from Rondônia and Roraima, Brazil

\begin{tabular}{|c|c|c|c|c|c|c|c|}
\hline Population & $\begin{array}{l}\text { Sample } \\
\text { size }(\mathrm{N})\end{array}$ & $\begin{array}{c}\text { Number of } \\
\text { genotypes }\end{array}$ & $\begin{array}{l}\text { Site-specific and } \\
\text { shared genotypes }\end{array}$ & $\begin{array}{c}\text { Genotypic } \\
\text { diversity }\left(\mathrm{G}_{\mathrm{O}}\right)^{\mathrm{x}}\end{array}$ & $\begin{array}{l}\text { Clonal } \\
\text { fraction }\end{array}$ & Evenness ${ }^{x, y}$ & $\begin{array}{c}\text { Allelic } \\
\text { richness }(\mathrm{AR})^{\mathrm{z}}\end{array}$ \\
\hline \multicolumn{8}{|l|}{ Colombia } \\
\hline COL BBT & 80 & 21 & $18(3)$ & $5.27 \mathrm{~cd}$ & 0.74 & $0.29 \mathrm{e}$ & $3.29 \mathrm{abc}$ \\
\hline COL_OS & 43 & 19 & $18(1)$ & $4.13 \mathrm{~d}$ & 0.56 & $0.23 \mathrm{f}$ & $2.78 \mathrm{bc}$ \\
\hline Total in Colombia & 204 & 68 & $65(3)$ & & 0.68 & & \\
\hline \multicolumn{8}{|l|}{ Brazil } \\
\hline RO_S & 20 & 19 & $19(0)$ & $17.34 \mathrm{a}$ & 0.05 & $0.96 \mathrm{a}$ & $4.33 \mathrm{a}$ \\
\hline RO_B3 & 37 & 23 & $20(3)$ & $11.97 \mathrm{bc}$ & 0.38 & $0.72 \mathrm{c}$ & $3.71 \mathrm{ab}$ \\
\hline$R R \quad R$ & 27 & 19 & $18(1)$ & $11.67 \mathrm{bc}$ & 0.30 & $0.73 \mathrm{c}$ & $2.56 \mathrm{c}$ \\
\hline Total in Brazil & 146 & 112 & $107(5)$ & & 0.22 & & \\
\hline Overall total & 350 & 180 & $172(8)$ & & & & \\
\hline
\end{tabular}

${ }^{w}$ Number of genotypes shared with other populations are shown in parentheses.

${ }^{x}$ Means followed by the same letter are not significantly different according to a pairwise test for differences in clonal diversity indices among populations, with 1,000 permutations per bootstrap resampling. For $G_{O}$, subsamplings were used to match the size of the smallest population, with 20 individuals.

y Evenness equal to 1.0 indicates that all genotypes exhibited identical frequencies in the population.

z Comparisons between mean allelic richness (with rarefaction, based on a sample of 19 diploid individuals) were performed using FSTAT 2.9.3.2. (Goudet 1995) based on 1,000 permutations; means followed by the same letter are not significantly different $(P \geq 0.05)$. Calculated according to El Mousadik and Petit (1996).

TABLE 3. Tests of random allelic association within each locus and between pairs of loci in Rhizoctonia solani anastomosis group-1 IA populations from signalgrass and rice in Colombia and Brazil

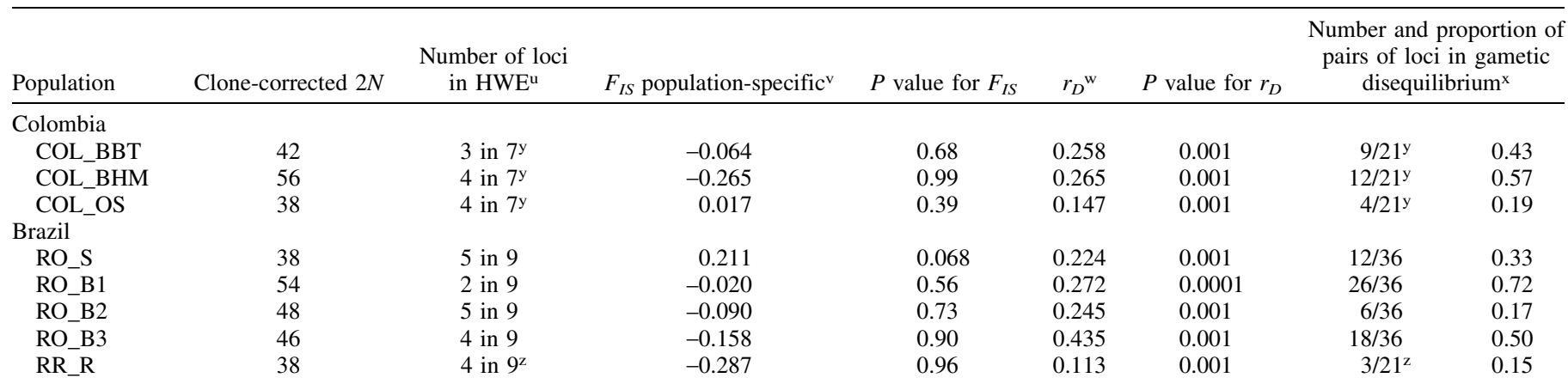

u Test analogous to the Fisher's exact test. $P$ values were obtained using Markov Chain Monte Carlo in ARLEQUIN 3.11 (Excoffier et al. 2005) with $P \leq 0.05$ following Bonferroni's correction for multiple comparisons.

${ }^{v}$ Inbreeding coefficient $\left(F_{I S}\right)$ and $P$ values determined using ARLEQUIN 3.11 .

${ }^{\mathrm{w}} r_{D}$ is a multilocus disequilibrium index (Maynard Smith et al. 1993) corrected for the total number of loci. Significance was determined using both MULTILOCUS 1.3 (Agapow and Burt 2001) and the poppr 1.0.5 R package (Kamvar et al. 2014) with 1,000 randomizations.

${ }^{x}$ Fisher's exact test performed using GENEPOP 3.4 (Raymond and Rousset 1995) at $P \leq 0.05$ following Bonferroni correction for multiple comparisons.

y Two monomorphic loci (T10 and TC13).

${ }^{\mathrm{z}}$ Two loci with a single heterozygous genotype (TC02 and TC07). 
genotype ( $\mathrm{k}=8$ populations was also the most likely number of groups) considering an admixture model with lambda $=0.63$ defined a priori.

Phylogeography of $\boldsymbol{R}$. solani AG-1 IA lineages. Historical migration rates among populations from Brazil and Colombia were estimated using a Bayesian method based on coalescent theory as proposed by Beerli and Felsenstein (2001). This method permits estimation of the effective population size or theta $(\theta)(\theta=4 N e \mu$ for diploids, where $N e$ is the effective population size and $\mu$ is the mutation rate) and the asymmetric historical migration rate $(M=4 \mathrm{Nm}$, where $\mathrm{Nm}$ is the number of migrants per generation) between two populations, indicating the likely migration route of the pathogen. The three $R$. solani populations from Urochloa in Brazil were combined into a single population to decrease the number of parameter pairs to be estimated. Historical migration between populations was estimated with MIGRATE 3.0.3 (Beerli and Felsenstein 2001) using 10 runs with 1,000,000 iterations per run. The run with the highest likelihood was chosen to represent the migration pattern.

Three nuclear DNA loci $(R 44 L, R 68 L$ and $R 116 L$ [Ciampi et al. 2009]) were sequenced from $R$. solani AG-1 IA isolates belonging

TABLE 4. Measures of differentiation between populations of Rhizoctonia solani anastomosis group-1 IA from signalgrass, rice, and soybean in Colombia and Brazil based on $R_{S T}{ }^{\mathrm{z}}$

\begin{tabular}{|c|c|c|c|c|c|c|c|}
\hline & COL_BBT & COL_BHM & COL_OS & RO_S & RO_B1 & RO_B2 & RO_B3 \\
\hline \multicolumn{8}{|l|}{ Colombia } \\
\hline COL_BBT & - & & & & & & \\
\hline COL_BHM & $0.057 * *$ & - & & & & & \\
\hline \multicolumn{8}{|l|}{ Brazil } \\
\hline RO_S & $0.174 * * *$ & $0.173 * * *$ & $0.310 * * *$ & - & & & \\
\hline RO_B1 & $0.105 * * *$ & $0.014^{\mathrm{NS}}$ & $0.094 * *$ & $0.119 * * *$ & - & & \\
\hline RO_B2 & $0.123 * * *$ & $0.071 * * *$ & $0.139 * * *$ & $0.141 * *$ & $0.116 * * *$ & - & \\
\hline
\end{tabular}

${ }^{\mathrm{z}} R_{S T}$ is the fixation index between populations. $*=P \leq 0.05, * *=P \leq 0.01, * * *=P \leq 0.001$ and NS = not significant.

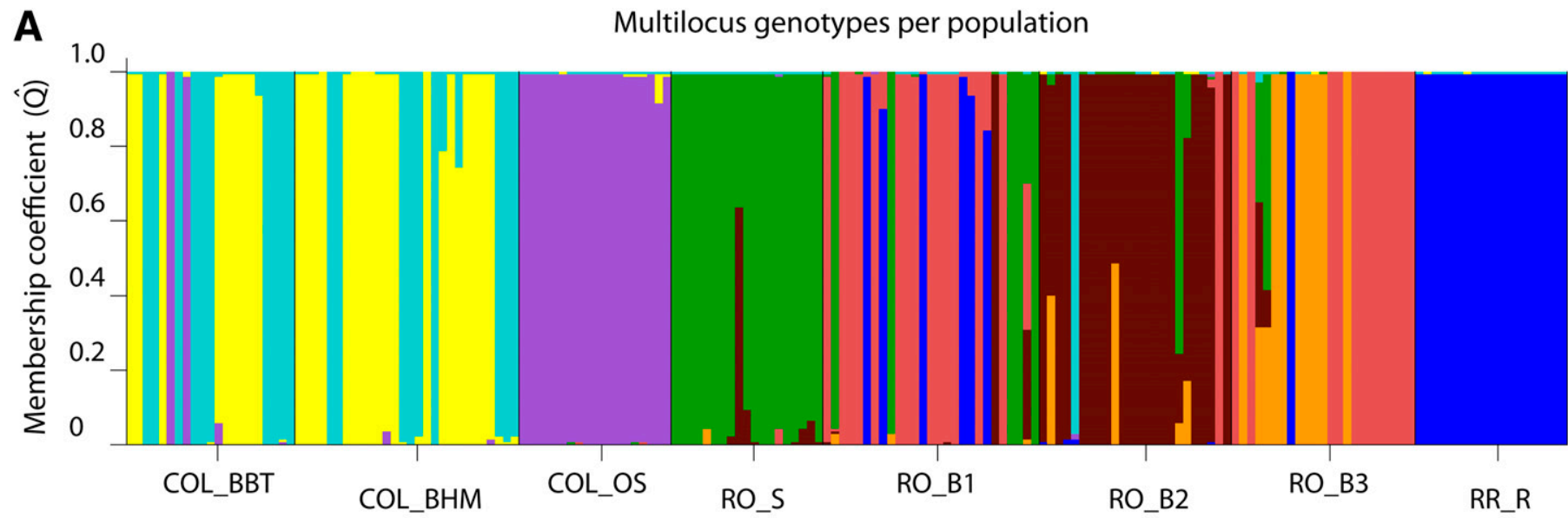

B

\begin{tabular}{|c|c|c|c|c|c|c|c|c|c|c|c|}
\hline \multirow{3}{*}{ Populations } & \multicolumn{8}{|c|}{ Number of genotypes with membership coefficient in the origin population or in other populations } & \multirow{3}{*}{$\begin{array}{l}\text { Total } \\
\text { number of } \\
\text { genotypes }\end{array}$} & \multirow{3}{*}{$\begin{array}{l}\text { Number of } \\
\text { admixed } \\
\text { genotypes }\end{array}$} & \multirow{3}{*}{$\begin{array}{l}\text { Admixture } \\
\text { proportion }\end{array}$} \\
\hline & \multicolumn{3}{|l|}{ Colombia } & \multicolumn{5}{|l|}{ Brazil } & & & \\
\hline & COL_BBT & COL_BHM & COL_OS & RO_S & RO_B1 & RO_B2 & RO_B3 & $R R \_R$ & & & \\
\hline \multicolumn{12}{|l|}{ Colombia } \\
\hline COL_BBT & 10.0 & 8.9 & 2.1 & 0.0 & 0.0 & 0.0 & 0.0 & 0.0 & 21 & 10.9 & 0.52 \\
\hline COL_BHM & 9.4 & 18.5 & 0.1 & 0.0 & 0.0 & 0.0 & 0.0 & 0.0 & 28 & 9.4 & 0.34 \\
\hline COL_OS & 0.0 & 0.1 & 18.8 & 0.0 & 0.0 & 0.0 & 0.0 & 0.0 & 19 & 0.2 & 0.01 \\
\hline \multicolumn{12}{|l|}{ Brazil } \\
\hline RO_S & 0.0 & 0.0 & 0.0 & 17.9 & 0.1 & 0.9 & 0.1 & 0.0 & 19 & 1.1 & 0.06 \\
\hline RO_B1 & 0.0 & 0.0 & 0.0 & 5.2 & 14.7 & 1.3 & 0.1 & 5.7 & 27 & 12.3 & 0.46 \\
\hline RO_B2 & 1.0 & 0.0 & 0.0 & 1.0 & 1.0 & 19.8 & 1.1 & 0.0 & 24 & 4.2 & 0.18 \\
\hline RO_B3 & 0.0 & 0.0 & 0.0 & 0.9 & 12.0 & 0.4 & 8.6 & 1.0 & 23 & 14.4 & 0.63 \\
\hline \multirow[t]{2}{*}{$R R \_R$} & 0.0 & 0.0 & 0.0 & 0.0 & 0.0 & 0.0 & 0.0 & 19.0 & 19 & 0.0 & 0.00 \\
\hline & & & & & & & & Total & 180 & 52.6 & 0.29 \\
\hline
\end{tabular}

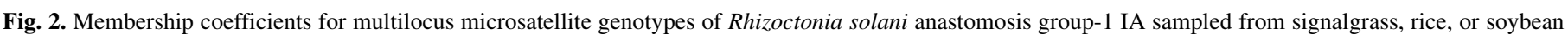

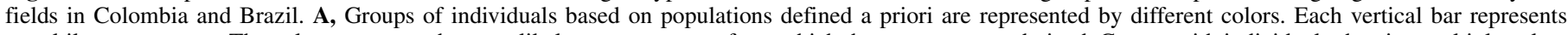

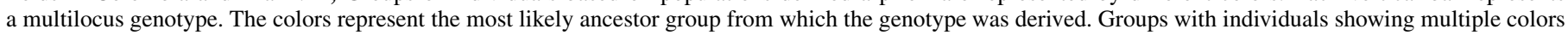

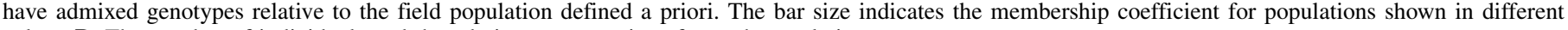
colors. B, The number of individuals and the admixture proportions for each population. 
to different multilocus SSR genotypes obtained from different host populations at two sites: from Urochloa and rice in Colombia $(n=$ 13 isolates, totaling 26 haplotypes) and from Urochloa and soybean in Brazil ( $n=15$ isolates, totaling 30 haplotypes). Our hypothesis was that $R$. solani AG-1 IA populations from different hosts would share multigene lineages, indicating a common origin for these populations. The sequences were aligned using Geneious. Because $R$. solani AG-1 IA is heterokaryotic, the different phases of the heterozygous sequences were analyzed using the algorithm implemented in PHASE 2.1.1

TABLE 5. Estimates of demographic parameters of divergence between different host populations of Rhizoctonia solani anastomosis group-1 IA infecting signalgrass, rice, and soybean in Brazil and Colombia ${ }^{\mathrm{y}}$

\begin{tabular}{|c|c|c|c|c|c|c|c|c|c|c|c|}
\hline \multirow{2}{*}{$\begin{array}{l}\text { Demographic } \\
\text { parameters }\end{array}$} & \multicolumn{4}{|c|}{ Quantiles $^{z}$} & \multirow{2}{*}{\multicolumn{7}{|c|}{ Comparison of means }} \\
\hline & $2.50 \%$ & Mode & $97.50 \%$ & & & & & & & & \\
\hline \multicolumn{12}{|l|}{ Population size } \\
\hline$\theta_{1}\left(\mathrm{RO} \_\mathrm{B}\right)$ & 0.0 & 1.5 & 3.2 & & & & & & & & \\
\hline$\theta_{2}\left(\mathrm{RO} \_\mathrm{S}\right)$ & 0.0 & 1.1 & 2.8 & & & & & & & & \\
\hline$\theta_{3}\left(\mathrm{RR} \_\mathrm{R}\right)$ & 0.0 & 1.9 & 3.6 & & & & & & & & \\
\hline$\theta_{4}\left(\mathrm{COL} \_\mathrm{BBT}\right)$ & 0.0 & 0.7 & 2.6 & & & & & & & & \\
\hline$\theta_{5}\left(\mathrm{COL} \_\mathrm{BHM}\right)$ & 0.0 & 1.1 & 2.8 & & & & & & & & \\
\hline$\theta_{6}\left(\mathrm{COL} \_\mathrm{OS}\right)$ & 0.0 & 1.9 & 3.8 & & & & & & & & \\
\hline \multicolumn{12}{|c|}{ Historical migration rates to specific populations } \\
\hline$\theta_{1} M 2 \rightarrow 1$ (RO_B) & 22.2 & 26.9 & 36.4 & & & & & $\mathrm{f}$ & $\mathrm{g} \mathrm{h}$ & & \\
\hline$\theta_{1} M 3 \rightarrow 1$ & 13.0 & 18.5 & 23.6 & & & & & & & h i & \\
\hline$\theta_{1} M 4 \rightarrow 1$ & 9.8 & 15.1 & 19.0 & & & & & & & & $\mathrm{j}$ \\
\hline$\theta_{1} M 5 \rightarrow 1$ & 9.0 & 15.1 & 21.4 & & & & & & & $\mathrm{i}$ & $\mathrm{j}$ \\
\hline$\theta_{1} M 6 \rightarrow 1$ & 17.0 & 26.7 & 31.6 & & & & & & $\mathrm{~g} h$ & hi & $\mathrm{j}$ \\
\hline$\theta_{2} M 1 \rightarrow 2$ (RO_S) & 69.8 & 82.3 & 100.0 & $\mathrm{a}$ & & & & & & & \\
\hline$\theta_{2} M 3 \rightarrow 2$ & 14.8 & 20.1 & 29.0 & & & & & & $\mathrm{~g} \mathrm{~h}$ & $\mathrm{~h} i$ & \\
\hline$\theta_{2} M 4 \rightarrow 2$ & 27.0 & 47.3 & 55.2 & & & c d & $\mathrm{e}$ & $\mathrm{f}$ & $\mathrm{g}$ & & \\
\hline$\theta_{2} M 5 \rightarrow 2$ & 38.4 & 55.7 & 67.6 & & $\mathrm{~b}$ & $\mathrm{c} \mathrm{d}$ & & & & & \\
\hline$\theta_{2} M 6 \rightarrow 2$ & 63.2 & 81.3 & 99.2 & $\mathrm{a}$ & b & & & & & & \\
\hline$\theta_{3} M 1 \rightarrow 3$ (RR_R) & 62.0 & 93.5 & 100.0 & $\mathrm{a}$ & b & & & & & & \\
\hline$\theta_{3} M 2 \rightarrow 3$ & 30.2 & 41.3 & 55.2 & & & c d & $\mathrm{e}$ & $\mathrm{f}$ & & & \\
\hline$\theta_{3} M 4 \rightarrow 3$ & 18.2 & 26.1 & 33.0 & & & & & & $\mathrm{~g} \mathrm{~h}$ & $\mathrm{hi}$ & \\
\hline$\theta_{3} M 5 \rightarrow 3$ & 11.0 & 16.9 & 25.8 & & & & & & $\mathrm{~h}$ & $\mathrm{hi}$ & $\mathrm{j}$ \\
\hline$\theta_{3} M 6 \rightarrow 3$ & 33.2 & 45.3 & 62.2 & & & c d & $\mathrm{e}$ & & & & \\
\hline \multicolumn{12}{|l|}{$\theta_{4} M 1 \rightarrow 4$} \\
\hline (COL_BBT) & 46.4 & 53.1 & 84.6 & $\mathrm{a}$ & b & $\mathrm{c}$ & & & & & \\
\hline$\theta_{4} M 2 \rightarrow 4$ & 15.8 & 26.3 & 32.8 & & & & & & $\mathrm{~g} \mathrm{~h}$ & h i & $\mathrm{j}$ \\
\hline$\theta_{4} M 3 \rightarrow 4$ & 24.4 & 37.5 & 43.6 & & & d & $1 \mathrm{e}$ & $\mathrm{f}$ & $\mathrm{g}$ & & \\
\hline$\theta_{4} M 5 \rightarrow 4$ & 27.8 & 37.9 & 71.8 & $\mathrm{a}$ & b & $\mathrm{c} \mathrm{d}$ & & & & & \\
\hline$\theta_{4} M 6 \rightarrow 4$ & 67.6 & 98.1 & 100.0 & $\mathrm{a}$ & b & & & & & & \\
\hline \multicolumn{12}{|l|}{$\theta_{5} M 1 \rightarrow 5$} \\
\hline (COL_BH & 41.8 & 57.1 & 67.6 & & b & c d & & & & & \\
\hline$\theta_{5} M 2 \rightarrow 5$ & 29.2 & 37.5 & 52.8 & & & c d & $\mathrm{e}$ & $\mathrm{f}$ & & & \\
\hline$\theta_{5} M 3 \rightarrow 5$ & 18.6 & 26.7 & 43.4 & & & $\mathrm{~d}$ & $\mathrm{e}$ & $\mathrm{f}$ & $\mathrm{g} \mathrm{h}$ & h i & $\mathrm{j}$ \\
\hline$\theta_{5} M 4 \rightarrow 5$ & 50.0 & 58.3 & 71.2 & $\mathrm{a}$ & b & $\mathrm{c}$ & & & & & \\
\hline$\theta_{5} M 6 \rightarrow 5$ & 19.2 & 30.1 & 36.2 & & & & & $\mathrm{f}$ & $\mathrm{g} \mathrm{h}$ & hi & $\mathrm{j}$ \\
\hline \multicolumn{12}{|l|}{$\theta_{6} M 1 \rightarrow 6$} \\
\hline (COL_OS) & 0.0 & 1.3 & 3.2 & & & & & & & & \\
\hline$\theta_{6} M 2 \rightarrow \overline{6}$ & 0.0 & 1.1 & 2.8 & & & & & & & & \\
\hline$\theta_{6} M 3 \rightarrow 6$ & 0.0 & 1.9 & 4.0 & & & & & & & & \\
\hline$\theta_{6} M 4 \rightarrow 6$ & 20.6 & 27.5 & 32.6 & & & & & & $\mathrm{~g} \mathrm{~h}$ & $\mathrm{hi}$ & $\mathrm{j}$ \\
\hline$\theta_{6} M 5 \rightarrow 6$ & 0.0 & 1.3 & 3.2 & & & & & & & & \\
\hline
\end{tabular}

$y$ Theta $(\theta)$ values provide a measure of the effective population size. For diploids, $\theta=4 \mathrm{Ne} \mu$, where $\mathrm{Ne}=$ effective population size and $\mu=$ mutation rate for each locus. The migration rate $M(\theta M)$ between host populations was estimated using an isolation-with-migration model in MIGRATE v.3.0.3 software. $\theta$ or migration rate values followed by different letters in the same column are significantly different based on parameter estimates at $95 \%$.

${ }^{z}$ Bayesian estimates of $95 \%$ credibility intervals for each parameter are given by the 0.025 and 0.975 quantiles of its a posteriori distribution. The harmonic mean of the data log-probability considering the established model was -800.69 for the combined analysis of the Colombian and Brazilian pathogen populations.
(Stephens et al. 2001) to infer the alleles for each genotype. To test the assumptions of the phylogenetic analysis, four neutrality tests were performed: Ewens-Watterson (Ewens 1972; Watterson 1975), Chakraborty (Chakraborty 1990), Tajima's D (Tajima 1989), and Fu and Li's FS (Fu and Li 1993). The best-fit nucleotide substitution model was determined using the hierarchical likelihood ratio test (ML) in MEGA 5.0 software (Tamura et al. 2011). All the sequences obtained in this study for the three nuclear DNA loci were deposited at GenBank, National Center for Biotechnology Information (R44 L, from KP129201 to KP129266; R68 L, from KP140701 to KP140768; and R116 L, from KP140769 to KP140838).

The phylogeographic history of multigene lineages infecting signalgrass, rice, and soybean was reconstructed using analyses based on ancestral reconstruction and discrete phylogeography coalescence using BEAST 2.0 (Bouckaert et al. 2014). The phylogenetic relationships between lineages were determined through a coalescent Bayesian approach using the Metropolis-coupled MCMC (MCMCMC) method with 100,000,000 generations. Ten different runs were performed with the same number of generations. The run with the highest likelihood was chosen to represent the phylogeographic history of the lineages, and the maximum clade credibility tree was determined using the Tree-Annotator module of BEAST 2.0 (Bouckaert et al. 2014).

Cross pathogenicity of $R$. solani AG-1 IA isolates. Twelve $R$. solani AG-1 IA isolates from Urochloa and 12 isolates from rice were selected to test cross pathogenicity on rice 'Fedearroz 50' and $U$. brizantha 'Toledo'. Uninoculated control plants were included in the assay. Rice and Urochloa were sown in plastic pots containing a soil and sand mix (2:1) and fertilized with $1 \mathrm{~g}$ of 15-15-15 (NPK). Seeds were surface-sterilized with $2.5 \%$ sodium hypochlorite for 20 min prior to sowing. Four seeds were sown in each pot. The two hosts were inoculated with the 24 isolates. A complete randomized block design with three replicates was used and the entire experiment was repeated once.

Inoculation with $R$. solani sclerotia was performed when the plants had four leaves. The inoculum was applied to the base of the last or second-to-last leaf of the main tiller and attached with Parafilm. The infected plants were kept in a phytotron under high humidity (95\%) with daytime temperatures kept between 25 to $27^{\circ} \mathrm{C}$. Evaluation was performed 6 days after inoculation on rice and 12 days after inoculation on Urochloa by measuring the maximum tiller length and the lesion length on the tiller. A disease index was calculated according to the following equation: the length of the lesion on the tiller was divided by the maximum tiller length and multiplied by nine (Jia et al. 2007). The rating of the experimental unit was the combined scores from the four plants. To detect evidence of host specialization, analysis of variance followed by a priori contrast analysis between groups of isolates was performed using SAS 9.1 (SAS System for Windows, SAS Institute, Cary, NC). The statistical analyzes were performed independently for each experiment.

Pathogenicity of $R$. solani AG-1 IA isolates from Urochloa to the Fabaceae cowpea and soybean. To determine whether $R$. solani AG-1 IA isolates adapted to Urochloa spp. can infect Fabaceae species, $12 R$. solani AG-1 IA isolates from $U$. brizantha 'Toledo', and 12 isolates from the Urochloa hybrid Mulato were inoculated onto two Fabaceae species: cowpea cultivar IT86D-719 (Nechet and Halfeld-Vieira 2007) and soybean cultivar FT-16 (Nechet et al. 2008). Two different experiments were performed, one for each host. The experiments were set up, conducted, and evaluated as in previous studies (Bernardes de Assis et al. 2008; González-Vera et al. 2010). Briefly, the experiments used a complete randomized block design with five replicates and were repeated once. Disease severity was evaluated by photographing at least one infected leaf per plant and measuring the diseased leaf area using the image analysis software ASSESS (ASSESS: Image Analysis Software for Plant Disease Quantification, L. Lamari, Department of Plant Science, University of Manitoba, Winnipeg, Manitoba, Canada). An analysis of variance followed by planned contrast analysis for comparisons between groups 
of isolates was performed as previously described. The statistical analyses were performed independently for each experiment.

\section{RESULTS}

Gene and genotype diversity. All nine microsatellite markers were polymorphic. The average allelic richness of the eight populations was 3.50. Allelic richness was not significantly different among populations originating from soybean or Urochloa in Brazil and in Colombia (AR ranged from 3.29 to 4.33). Populations COL_OS and RR_R, both from rice, exhibited lower allelic richness than the remaining populations ( $\mathrm{AR}=2.56$ to 2.78 ) (Table 2$)$.

One hundred eighty different multilocus genotypes were found among the 350 isolates analyzed (Table 2). Although 172 of the multilocus genotypes were site-specific, three were shared among Urochloa and rice fields in Colombia, and five were shared among Urochloa and rice fields in Brazil. In Colombia, two genotypes were shared by U. brizantha 'Toledo' (COL_BBT) and Urochloa hybrid Mulato (COL_BHM) populations, and one was also shared with the rice population (COL_OS). In Brazil, five genotypes were shared among RO_B1 and all the remaining populations, including the allopatric rice population RR_R from Roraima. No genotype was shared with the soybean population (RO_S) and no genotypes were shared between populations from Colombia and Brazil.

The effective number of genotypes, a measure of genotypic diversity, was higher for soybean (RO_S) and Urochloa (RO_B1) populations, which exhibited genotypic diversity $G_{O}$ of 17.3 and 16.5 , respectively, values significantly higher than those found in the Colombian populations. The three populations with the lowest genotypic diversity (COL_BBT, COL_BHM and COL_OS) exhibited $G_{O}$ values ranging from 4.1 to 5.3. The clonal fraction varied from very low ( 0.05 for soybean population RO_S) to very high ( 0.74 for U. brizantha 'Toledo' population COL_BBT). Evenness ranged from 0.23 for population
COL_OS to 0.88 for population RO_B1 and 0.96 for population RO_S. In general, the genotypes found in the rice population COL_OS were not uniformly distributed, whereas a more even distribution of genotypes was detected for the Urochloa RO_B1 and soybean populations.

Population genetic structure. A significant deviation from HWE was observed for most of the field populations; only two to four SSR loci were in HWE in populations COL_BBT, COL_BHM, COL_OS, RO_B1, RO_B3, and RR_R (Table 3). In contrast, most of the SSR loci were in HWE in the RO_S and RO_B2 populations. $F_{\text {IS }}$ coefficients per population were not significantly different from zero, indicating that inbreeding was not significant in any of the populations (Table 3). Disequilibrium among loci was observed in all populations $\left(r_{D}\right.$ significant at $P \leq 0.001$ ). The proportion of locus pairs in disequilibrium varied between 0.15 (RR_R) and 0.57 (COL_BHM) (Table 3).

The overall fixation index $R_{S T}$ of $0.145(P \leq 0.001)$ indicated significant differentiation among geographical and host populations from Urochloa, soybean, and rice from Brazil and Colombia. Most population pairs were significantly differentiated, but populations COL_BHM, RO_B1, and RO_B3 from Urochloa did not exhibit genetic differentiation, consistent with gene flow over short and long distances. No differentiation was observed between populations COL_BHM from Urochloa and COL_OS from rice (Table 4).

Overall, 29\% admixture was detected for sympatric (from the same region) and allopatric (from different regions) populations of $R$. solani AG-1 IA from signalgrass, rice and soybean. This corresponded to 52 genotypes that could have originated from populations different from their reference populations (Fig. 2). The degree of admixture varied from a minimum of $6 \%$ for population RO_S (only one admixed genotype) to a maximum of $63 \%$ for RO_B3 (equivalent to 14 admixed genotypes). All populations sampled from Urochloa exhibited a high proportion of admixed genotypes. No admixed genotypes were observed in pathogen populations infecting rice in either Colombia

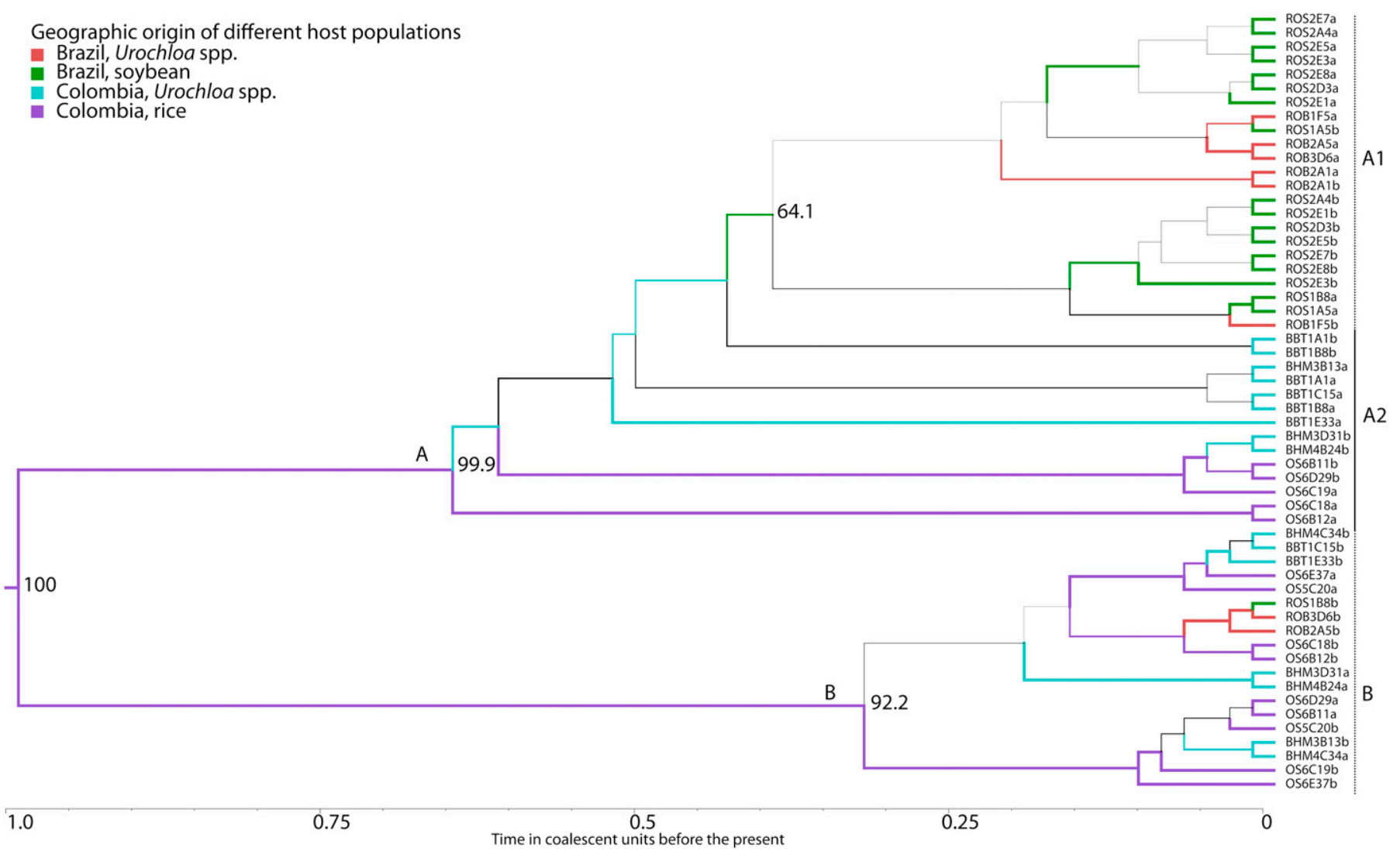

Fig. 3. Maximum clade credibility tree based on Bayesian coalescent phylogenetic reconstruction illustrating the phylogenetic relationships among Rhizoctonia solani anastomosis group-1 IA isolates from signalgrass, rice, or soybean in Brazil and Colombia. Credibility values are shown for the three main lineages, A1, A2, and B. Branch colors represent different geographical and host origins. Branch thickness is proportional to the posterior probability node support within lineages. 
or Roraima, Brazil. Population COL_BBT exhibited two admixed genotypes that were attributed to the rice population. Population RO_B1 exhibited five mixed genotypes that were attributed to the nearby soybean population.

Phylogeography of $R$. solani AG-1 IA lineages from different hosts. No significant differences were found in the population size estimates of Brazilian and Colombian populations infecting signalgrass, rice, and soybean (Table 5). A high asymmetry was found in historical migration rates among different geographic and host populations. The migration rates from the Colombian population infecting rice (COL_OS) to the two Urochloa populations (COL_BBT and COL_BHM) $\left(\theta_{4} M_{6 \rightarrow 4}=98.1\right.$ and $\left.\theta_{5} M_{6 \rightarrow 5}=30.1\right)$ were significantly higher than the migration rates in the opposite direction (Table 5). The migrant exchange between COL_OS and COL_BBT was also asymmetric; COL_OS contributed 23 times more migrants to population COL_BHM than it received from that population. The rates of migration into the Brazilian population infecting Urochloa (RO_B) from the five remaining populations were similar $\left(\theta_{1} M_{\mathrm{x} \rightarrow 1}\right.$ varied between 15.1 and 26.9 migrants/generation), indicating that population RO_B received similar proportions of migrants from all populations sampled in Brazil and Colombia. However, population RO_B contributed approximately four times more migrants to four of the five populations $\left(\theta_{\mathrm{x}} M_{1 \rightarrow \mathrm{x}}\right.$ varying between 53.1 and 93.5$)$, the exception being the COL_OS population that received only 1.3 migrants/generation.

The neutrality tests indicated neutral evolution for all three sequence loci $(R 44 L, R 68 L$, and $R 116 L)$ in the four pathogen populations (Supplementary Table S1). The Bayesian maximum clade credibility tree indicated two main phylogenetic clades, A and B, with posterior probabilities higher than $99 \%$ for group A and $92 \%$ for group B (Fig. 3). The phylogeographic analysis indicated that the most likely common ancestor of both clades originated from a rice population (shown in purple in Figure 3). Clade A, which was older, originated at 0.65 coalescence units, whereas clade B originated at approximately 0.34 coalescence units. Within clade A, there was support for subdivision into two subclades corresponding to the geographical origin of the isolates. The monophyletic subclade A-1 grouped the Brazilian isolates from soybean and Urochloa. The paraphyletic subclade A-2 grouped Colombian isolates from rice and Urochloa. The monophyletic clade B included mainly rice and Urochloa isolates from Colombia but also soybean and Urochloa isolates from Brazil.

Cross pathogenicity of $R$. solani AG-1 isolates from different hosts. $R$. solani AG-1 IA isolates from Urochloa
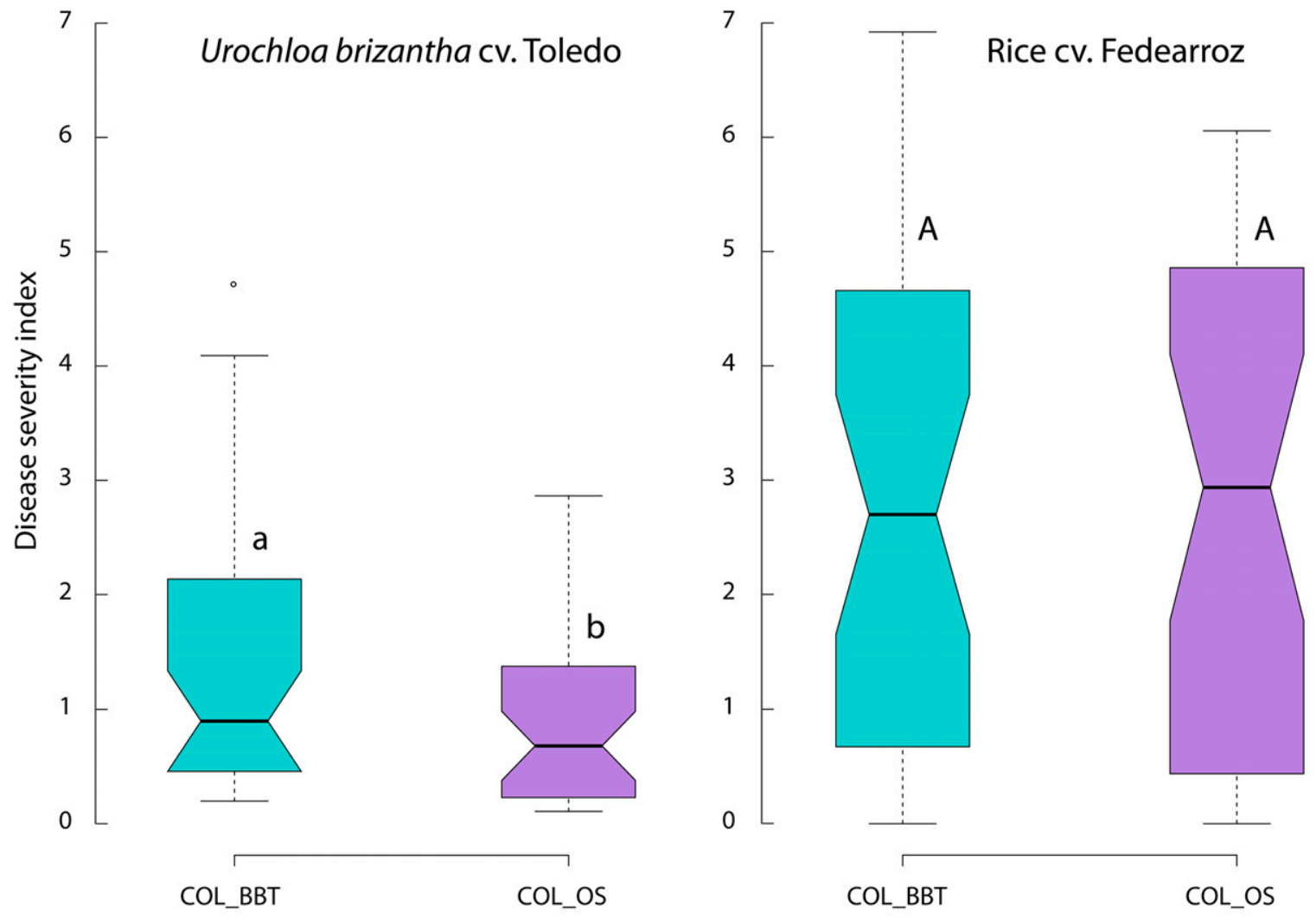

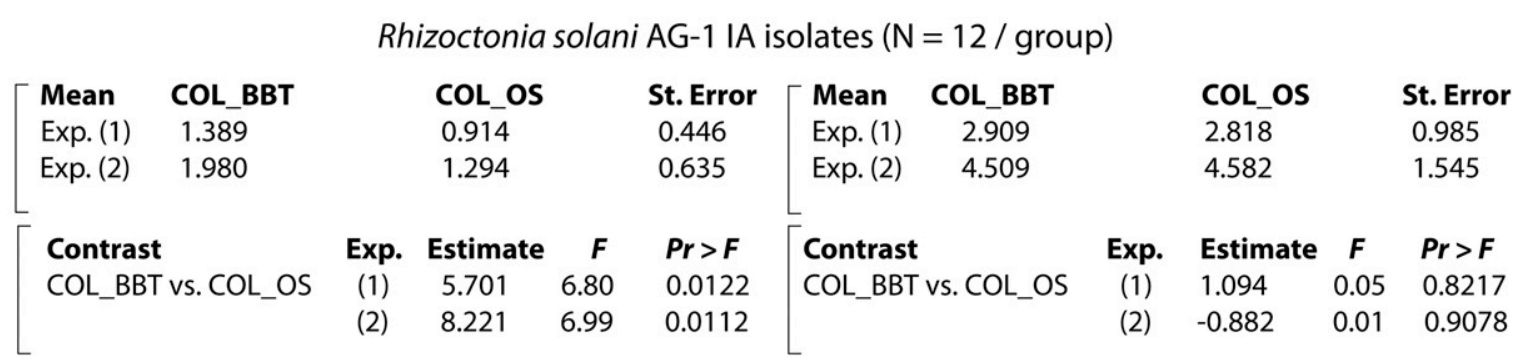

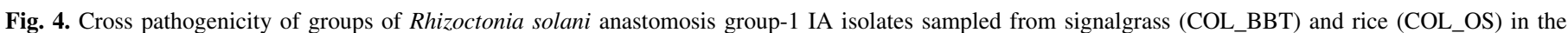

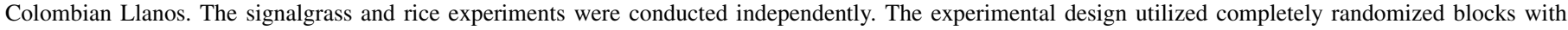

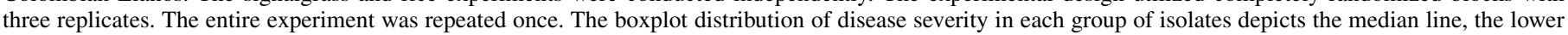

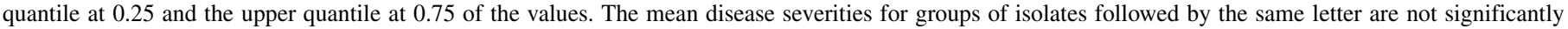
different by contrast of means at $P \leq 0.05$. No treatment by experiment interaction was detected, indicating full reproducibility of the experiments. 
(COL_BBT) were more aggressive to Urochloa than the rice isolates (COL_OS), consistent with incipient host specialization (Fig. 4). No significant differences were found between the two groups of isolates on rice.

Pathogenicity of $R$. solani AG-1 IA isolates from Urochloa to the Fabaceae cowpea and soybean. The two groups of isolates from Urochloa (from U. brizantha 'Toledo' [COL_BBT] or Urochloa hybrid Mulato [COL_BHM]) were highly aggressive on both cowpea and soybean (Fig. 5).

\section{DISCUSSION}

This study combined analyses of population genetic structure and phylogeography to explain the emergence of $R$. solani AG-1 IA causing the Urochloa foliar blight and collar rot in Colombia and Brazil. Pathogen populations infecting Urochloa were sampled from the Colombian Llanos and the Brazilian Amazon, where a high number of disease foci were observed in forage grass pastures. In addition to these populations, sympatric populations of $R$. solani AG-1 IA from rice in Colombia and from soybean in Rondônia, as well as an allopatric rice population in Roraima, were included to gain insight regarding the origin of the Urochloa pathogen populations.

Earlier population genetic analyses of $R$. solani AG-1 IA infecting rice, maize and soybeans found either mixed reproductive systems including both sexual reproduction and local clonal dispersal or mainly sexual reproductive systems (Bernardes-de-Assis et al. 2009; Ciampi et al. 2008; González-Vera et al. 2010; Linde et al. 2005; Rosewich et al. 1999). In general, the genetic structure of the $R$. solani AG-1 IA populations infecting Urochloa was largely clonal, but the clonecorrected datasets showed significant evidence for recombination, including many loci at HWE and random associations among many pairs of loci. Our interpretation is that $R$. solani AG-1 IA has a mixed reproductive system on Urochloa, with the relatively high clonality resulting from clones that have higher fitness on Urochloa (Xu 2005). The observed disequilibrium in the clone-corrected dataset could be explained largely by the Wahlund effect, reflecting admixture due to contemporary or historical gene and genotype flow among populations (Hartl and Clark 1997; Pritchard et al. 2000). There was little evidence for inbreeding as $F_{\text {IS }}$ values per population were not significant. The observed genetic structure indicates that populations of $R$. solani AG-1 IA infecting fields of Urochloa have a high evolutionary potential, as

\section{Cowpea cv. IT86D-719}

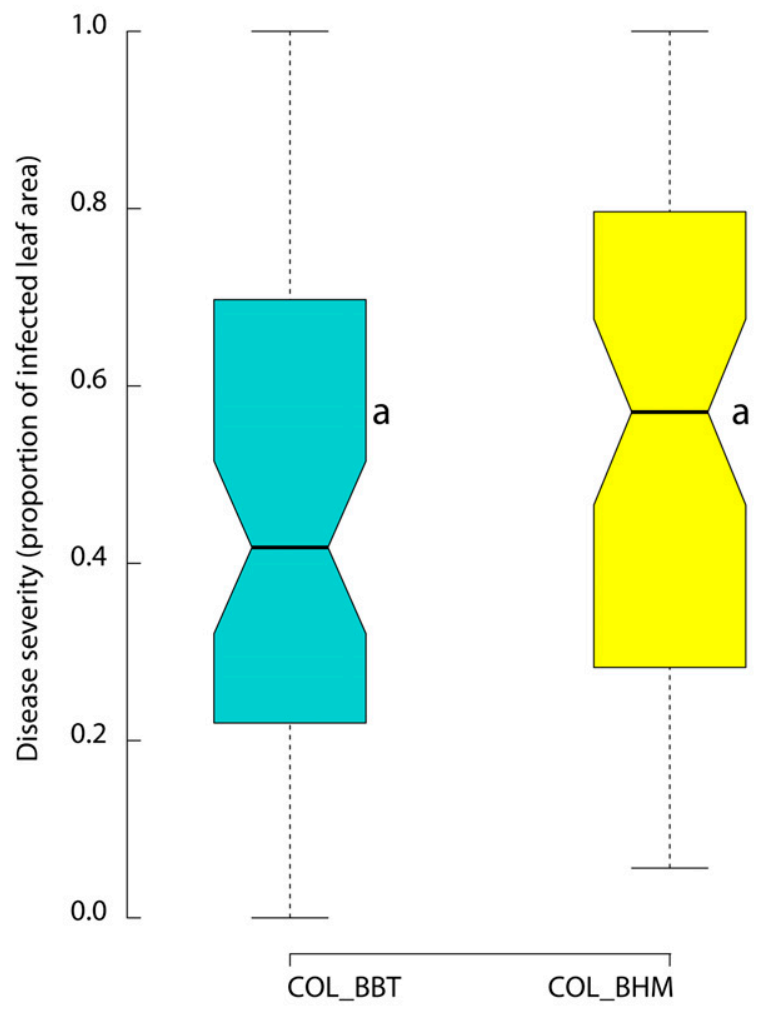

Soybean cv. FT16

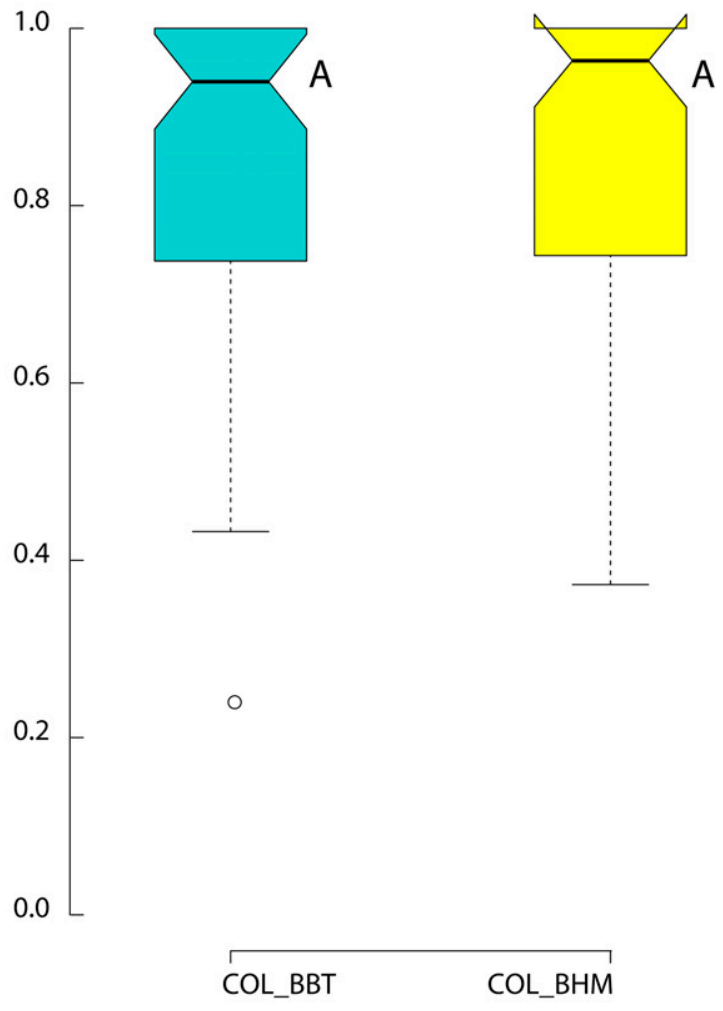

\begin{tabular}{|c|c|c|c|c|c|c|c|c|c|c|c|}
\hline Mean & \multicolumn{2}{|l|}{ COL_BBT } & \multicolumn{2}{|c|}{ COL_BHM } & St. Error & Mean & COL_BBT & & \multicolumn{2}{|l|}{ COL_BHM } & St. Error \\
\hline Exp. (1) & 0.471 & & 0.541 & & 0.126 & Exp. (1) & 0.851 & & 0.861 & & 0.0756 \\
\hline Exp. (2) & 0.498 & & 0.551 & & 0.108 & Exp. (2) & 0.836 & & 0.853 & & 0.0678 \\
\hline \multicolumn{2}{|c|}{ Contrast } & Exp. & Estimate & $\boldsymbol{F}$ & $\operatorname{Pr}>F$ & \multicolumn{2}{|c|}{ Contrast } & Exp. & Estimate & $\boldsymbol{F}$ & $\operatorname{Pr}>F$ \\
\hline \multirow{2}{*}{\multicolumn{2}{|c|}{ COL_BBT vs. COL_BHM }} & $(1)$ & -0.844 & 1.86 & 0.176 & \multirow{2}{*}{\multicolumn{2}{|c|}{ COL_BBT vs. COL_BHM }} & $(1)$ & -0.119 & 0.10 & 0.752 \\
\hline & & (2) & -0.640 & 1.46 & 0.230 & & & $(2)$ & -0.205 & 0.38 & 0.539 \\
\hline
\end{tabular}

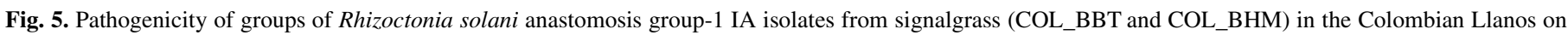

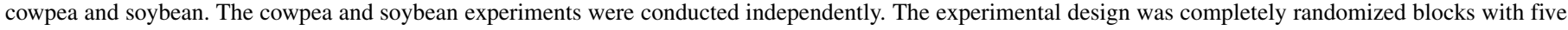

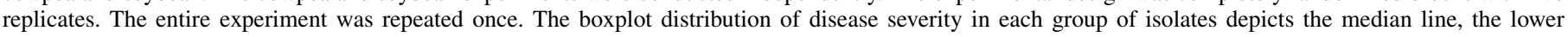

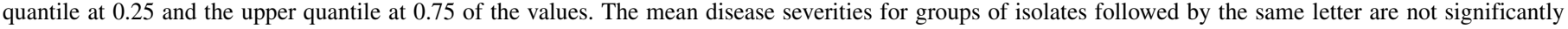
different by contrast of means at $P \leq 0.05$. No treatment by experiment interaction was detected, indicating full reproducibility of the experiments. 
previously described for $R$. solani AG-1 IA on other hosts (Bernardes-deAssis et al. 2009; Ciampi et al. 2008; Ferrucho et al. 2013; GonzálezVera et al. 2010). This suggests that disease management strategies based on single-site systemic fungicides or breeding for major gene resistance should be carefully implemented to reduce the likelihood of boom and bust cycles (Barrett et al. 2008; Zhan et al. 2014).

We falsified the hypothesis that geographical and host populations of $R$. solani AG-1 IA from signalgrass, rice, and soybean are genetically homogeneous (Table 4). Although significant subdivision was detected between the Urochloa populations from Colombia, the level of subdivision was relatively low $\left(R_{S T}=0.06\right)$ compared with the remaining population pairs. The high number of admixed genotypes between the two Colombian Urochloa populations (nine shared genotypes, representing 33 to $42 \%$ admixture; Fig. 2) provides strong evidence for contemporary gene and genotype flow among these populations. Contemporary gene flow was also indicated between the COL_BHM (Urochloa) and COL_OS (rice) populations sampled in the same region $\left(R_{S T}=0.001^{\mathrm{NS}}\right)$. Less recent historical migration was also found between the sympatric $R$. solani AG-1 IA populations from rice and Urochloa in Colombia, with the majority of migration from the rice- to the Urochloa-infecting populations. Our interpretation of these findings is that the populations of $R$. solani AG-1 IA currently infecting Urochloa in Colombia emerged through a host shift from an earlier $R$. solani AG-1 IA population infecting rice. This interpretation is further supported by the results of the phylogeographic analysis, which indicated that the most likely common ancestor for the $R$. solani AG-1 IA populations currently infecting Urochloa in Colombia and Brazil is the rice-infecting population.

Incipient ecological adaptation could explain the relatively low contemporary genetic divergence observed among the $R$. solani AG-1 IA populations sampled from rice and Urochloa in Colombia (Huyse et al. 2005; Kohn 2005). However, the pathogen populations sampled from Urochloa already exhibit signs of host specialization. The cross pathogenicity assays showed that pathogen isolates from Urochloa were more aggressive on Urochloa than the isolates from rice. A similar pattern consistent with host specialization was found among populations of $R$. solani AG-1 IA infecting maize and rice in Venezuela. Although the maize-infecting populations, which were more recently derived than the rice-infecting populations, were significantly differentiated $\left(R_{S T}=\right.$ 0.13 to $0.17 * * *)$, they shared historical migrants, leading to the interpretation that the maize-adapted populations originated from the rice-infecting populations growing in the same region via a host shift (González-Vera et al. 2010).

In Brazil, the Urochloa-adapted RO_B population from Rondônia contributed $\sim 50$ to 90 migrants/generation to most of the populations sampled. The interpretation of this pattern of high historical gene flow is that the Urochloa-adapted population is a major source of migrants to all other $R$. solani AG-1 IA populations, except COL_OS. The most plausible explanation for the high degree of long-distance gene flow observed among these populations is extensive dispersal of the pathogen on infected seeds of the widely cultivated $U$. brizantha ecotype 'Marandú', which is present in $\sim 50$ to $65 \%$ of the forage pastures in central-western and northern Brazil (Batistella and Moran 2005; Silva et al. 2013). Seedborne dispersal is favored by the intensive seed trade that occurs between Colombia and Brazil. Brazil is the world's largest producer and exporter of tropical forage plant seeds, including Urochloa, exporting to more than 20 countries. Forage seed export provides an income of approximately US\$250 million/year (Vechiato and Aparecido 2008). Current federal legislation established higher standards for the production of forage seeds (Ministério da Agricultura Pecuária e Abastecimento-Brasil 2008), specifically because the health quality of Urochloa seeds were considered low in the last decade, thus favoring the dispersal of several pathogens, including R. solani AG-1 IA (Fernandes et al. 2005; Mallmann et al. 2013). As an example, between 7.7 and $22.9 \%$ of the Urochloa commercial seed lots analyzed in the 2004 and 2006 cropping seasons were infested by Rhizoctonia, with an average incidence of approximately $1 \%$ of seeds infected (Marchi et al. 2010).
We postulate that two characteristics of the extensive Urochloa cultivation in Brazil facilitated both an increase in the $R$. solani AG-1 IA population adapted to Urochloa and its dispersal to rice and soybean crops growing in adjacent plantations. First, the rapid expansion of Urochloa grass pastures into the Amazon region brought Urochloa into areas planted to rice or soybeans (Prates and Bacha 2011), facilitating movement of the pathogen among cropping systems and enabling high levels of gene and genotype flow. Second, the cultivation of Urochloa pastures year-round (Batistella and Moran 2005; Silva et al. 2013) provided a continuous reservoir of inoculum that could infect neighboring crops (Marchi et al. 2011). The considerable migration indicated between Urochloa and soybean populations in Rondônia, Brazil (Table 5), and the pathogen's ability to infect other Fabaceae such as cowpea and soybean (Fig. 5), suggests that $R$. solani AG-1 IA also has the ability to jump between monocot and dicot hosts (Stukenbrock and McDonald 2008).

From an ecological point of view, the extensive cultivation of Urochloa in Brazil results in increased connectivity between pathogen populations and a consequent increase in the dynamics of disease development. The evolutionary and epidemiological consequences of this increased connectivity include a higher probability of accelerated evolution in the pathogen and an increased risk that a disease will become endemic or pandemic (Burdon and Thrall 2008; Thrall et al. 2011; Zhan et al. 2014). In fact, the connectivity between agricultural crops and natural components of rural landscapes has the potential to positively affect disease dynamics (dissemination and severity) as well as the evolution of plant pathogens in agroecosystems; consequently, a high connectivity may increase the rate at which new hostspecialized pathogen populations emerge (Burdon and Thrall 2008).

Concepts of agricultural landscape ecology that relate environmental spatial patterns to ecological and epidemiological processes can inform strategies to decrease the connectivity among agricultural crops and improve plant disease management (Mundt et al. 2010; Papaï et al. 2014a, b). The main goal of agroecological management of plant diseases is to increase spatial or temporal heterogeneity through habitat fragmentation or through fragmentation of agricultural landscapes in order to limit the propagation of plant pathogens among host populations (Mundt et al. 2010; Papaï et al. $2014 \mathrm{a}, \mathrm{b})$. To achieve this goal, the scale of disease management strategies must be elevated from the individual field to the regional agricultural landscape. While the goal of decreasing connectivity among susceptible host populations of $R$. solani AG-1 IA, including rice, soybean, cowpea, and Urochloa pastures, is theoretically sound, it is currently impractical in South American agroecosystems due to the vast scale of Urochloa cultivation. On the other hand, it could be practical to improve seed quality, for example through fungicide treatments or seed certification programs, to decrease the long-distance movement of seedborne pathogens on Urochloa seed. A long-term plan for agroecosystem development at the landscape scale will likely need to focus especially on managing plantings of Urochloa to disrupt the current movement of broadly adapted pathogens such as $R$. solani AG-1 IA among susceptible crops and prevent the emergence of more damaging host-specialized pathogen populations.

\section{ACKNOWLEDGMENTS}

E. Chavarro Mesa, P. C. Ceresini, and L. M. Ramos Molina contributed equally to this manuscript. This work was funded by a FAPESP (São Paulo Research Foundation, Brazil)-Biota research grant to P. C. Ceresini (2011/50150-3), research fellowships (Pq-2 308394/2009-7 and Pq-2 $307361 / 2012-8)$ and grants (481756/2010-8, 485244/2012-8, and 454543/2013-1) from CNPq (Brazilian National Council for Scientific and Technological Development) to P. C. Ceresini. E. Chavarro Mesa was supported by a PhD studentship from FAPESP (2011/23050-8), L. M. Ramos Molina by a PhD studentship from CNPq-DR (140564/2009-8), D. A. S. Pereira by an MSc studentship from FAPESP (2013/11944-0), and N. M. Poloni by an MSc studentship from CAPES. We thank A. Y. Perez Barragan (CNPq-AT 376421/2012-6), I. Lopez Garcia (CNPq-IC 117888/2013-3), 
M. M. Negrisoli (CNPq-IC 163835/2012-8), S. N. Campos (CNPq-AT 370186/2015-0), and M. Zala (ETH Zurich) for their technical assistance on this research.

\section{LITERATURE CITED}

Agapow, P.-M., and Burt, A. 2001. Indices of multilocus linkage disequilibrium. Mol. Ecol. Notes 1:101-102.

Alvarez, E., Latorre, M., Bonilla, X., Sotelo, G., and Miles, J. W. 2013. Diversity of Rhizoctonia spp. causing foliar blight on Brachiaria in Colombia and evaluation of Brachiaria genotypes for foliar blight resistance. Plant Dis. 97:772-779.

Argel, P. J., Miles, J. W., Guiot, J. D., and Lascano, C. E. 2005. Cultivar Mulato (Brachiaria híbrido CIAT 36061). Gramínea de alta producción y calidad forrajera para los trópicos. Palmira, CIAT (Centro Internacional de Agricultura Tropical).

Barrett, L. G., Thrall, P. H., Burdon, J. J., and Linde, C. C. 2008. Life history determines genetic structure and evolutionary potential of host-parasite interactions. Trends Ecol. Evol. 23:678-685.

Batistella, M., and Moran, E. F. 2005. Dimensões humanas do uso e cobertura das terras na Amazônia: Uma contribuição do LBA. Acta Amazon. 35: 239-247.

Beerli, P., and Felsenstein, J. 2001. Maximum likelihood estimation of a migration matrix and effective population sizes in $\mathrm{n}$ subpopulations by using a coalescent approach. Proc. Natl. Acad. Sci. USA 98:4563-4568.

Bernardes de Assis, J., Peyer, P., Rush, M. C., Zala, M., McDonald, B. A., and Ceresini, P. C. 2008. Divergence between sympatric rice- and soybeaninfecting populations of Rhizoctonia solani anastomosis group-1 IA. Phytopathology 98:1326-1333.

Bernardes-de-Assis, J., Storari, M., Zala, M., Wang, W., Jiang, D., ShiDong, L., Jin, M., McDonald, B. A., and Ceresini, P. C. 2009. Genetic structure of populations of the rice-infecting pathogen Rhizoctonia solani AG-1 IA from China. Phytopathology 99:1090-1099.

Black, B. D., Griffin, J. L., Russin, J. S., and Snow, J. P. 1996. Weed hosts for Rhizoctonia solani, causal agent for Rhizoctonia foliar blight of soybean (Glycine max). Weed Technol. 10:865-869.

Bolkan, H. A., and Ribeiro, W. R. C. 1985. Anastomosis groups and pathogenicity of Rhizoctonia solani isolates from Brazil. Plant Pathol. 69: 599-601.

Bouckaert, R., Heled, J., Kühnert, D., Vaughan, T., Wu, C.-H., Xie, D., Suchard, M. A., Rambaut, A., and Drummond, A. J. 2014. BEAST 2: A software platform for Bayesian evolutionary analysis. PLOS Comput. Biol. 10:e1003537.

Burdon, J. J., and Thrall, P. H. 2008. Pathogen evolution across the agroecological interface: Implications for disease management. Evol. Appl. 1: 57-65.

Cardona, R., Rodríguez, H., and Nass, H. 1999. Mancha bandeada en maíz causada por Rhizoctonia solani en el estado Portuguesa, Venezuela. Fitopatol. Venez. 12:32-33.

Cedeño, L., Nass, H., Carrero, C., Cardona, R., Rodríguez, H., and Alemán, L. 1996. Rhizoctonia solani AG-1-IA, causa principal del añublo de la vaina del arroz en Venezuela. Fitopatol. Venez. 9:6-9.

Chakraborty, R. 1990. Mitochondrial DNA polymorphism reveals hidden heterogeneity within some Asian populations. Am. J. Hum. Genet. 47:87-94

Chavarro Mesa, E., Pereira, D. A. S., Schurt, D. A., Vieira Júnior, J. R., and Ceresini, P. C. 2014. A etiologia complexa de doenças causadas por fungos do gênero Rhizoctonia em Brachiaria e em culturas simpátricas de arroz, feijão-caupi ou soja na Amazônia, nos Cerrados Brasileiros e no Vale do Paraíba. Congresso Brasileiro de Fitopatologia, 47. SBF (Sociedade Brasileira de Fitopatologia), Londrina, PR.

Chavarro Mesa, E., Ramos Molina, L. M., Silva Herrera, M. R., Conceição, G. H., and Ceresini, P. C. 2012. Etiologia e detecção molecular do patógeno da queima da folha da braquiária: Rhizoctonia solani AG-1 IA. Trop. Plant Pathol. 37:153.

Ciampi, M. B., Gale, L. R., Lemos, E. G. M., and Ceresini, P. C. 2009. Distinctively variable sequence-based nuclear DNA markers for multilocus phylogeography of the soybean- and rice-infecting fungal pathogen Rhizoctonia solani AG-1 IA. Genet. Mol. Biol. 32:840-846.

Ciampi, M. B., Kuramae, E. E., Fenille, R. C., Meyer, M. C., Souza, N. L., and Ceresini, P. C. 2005. Intraspecific evolution of Rhizoctonia solani AG-1 IA associated with soybean and rice in Brazil based on polymorphisms at the ITS-5.8S rDNA operon. Eur. J. Plant Pathol. 113:183-196.

Ciampi, M. B., Meyer, M. C., Costa, M. J. N., Zala, M., McDonald, B. A., and Ceresini, P. C. 2008. Genetic structure of populations of Rhizoctonia solani anastomosis group-1 IA from soybean in Brazil. Phytopathology 98: 932-941.

CIAT. 1993. Annual Report, Tropical Forages Program. Document Number 166. CIAT-Cali, Colombia, Cali.
Costa-Souza, E., Kuramae, E. E., Nakatani, A. K., Basseto, M. A., Prabhu, A. S., and Ceresini, P. C. 2007. Caracterização citomorfológica, cultural, molecular e patogênica de Rhizoctonia solani Kühn associado ao arroz em Tocantins, Brasil. Summa Phytopathol. 33:129-136.

Dall'Agnol, M., and Schifino-Wittmann, M. T. 2005. Apomixia, genética e melhoramento de plantas. R. bras. Agrociencia 11:127-133.

Duarte, M. L. R., Albuquerque, F. C., Sanhueza, R. M. V., Verzignassi, J. R., and Kondo, N. 2007. Etiologia da podridão do coleto de Brachiara brizantha em pastagens da Amazônia. Fitopatol. Bras. 32:261-265.

El Mousadik, A., and Petit, R. J. 1996. High level of genetic differentiation for allelic richness among populations of the argan tree [Argania spinosa (L.) Skeels] endemic to Morocco. Theor. Appl. Genet. 92:832-839.

Ewens, W. J. 1972. The sampling theory of selectively neutral alleles. Theor. Popul. Biol. 3:87-112.

Excoffier, L., Laval, G., and Schneider, S. 2005. Arlequin (version 3.0): An integrated software package for population genetics data analysis. Evol. Bioinf. 1:47-50.

Fernandes, C. D., Marchi, C. E., Jerba, V. F., and Borges, M. F. 2005. Patógenos associados às sementes de forrageiras tropicais e estratégias de controle. In: Sementes: Qualidade Fitossanitária. L. Zambolim, ed. Viçosa, UFV.

Ferrucho, R. L., Ceresini, P. C., Ramirez-Escobar, U. M., McDonald, B. A., Cubeta, M. A., and García-Domínguez, C. 2013. The Population genetic structure of Rhizoctonia solani AG-3PT from potato in the Colombian Andes. Phytopathology 103:862-869.

Fu, Y. X., and Li, W. H. 1993. Statistical tests of neutrality of mutations. Genetics 133:693-709.

Gaino, A. P. S. C., Basseto, M. A., Gasparotto, L., Poltronieri, L. S., and Ceresini, P. C. 2010. Phylogenetic inference reveals the complex etiology of the target and leaf spot diseases on rubber tree and other species cultivated in the Amazon. Acta Sci. Agron. 32:385-395.

Galindo, J. J., Abawi, G. S., Thurston, H. D., and Galvez, G. 1983. Source of inoculum and development of bean web blight in Costa Rica. Plant Dis. 67: 1016-1021.

González-Vera, A. D., Bernardes-de-Assis, J., Zala, M., McDonald, B. A., Correa-Victoria, F., Graterol-Matute, E. J., and Ceresini, P. C. 2010. Divergence between sympatric rice- and maize-infecting populations of Rhizoctonia solani AG 1 IA from Latin America. Phytopathology 100: 172-182.

Goudet, J. 1995. FSTAT (Version 1.2): A computer program to calculate F-statistics. J. Hered. 86:485-486.

Hartl, D. L., and Clark, A. G. 1997. Principles of Population Genetics, 3rd ed. Sinauer Associates, Sunderland, MA.

Hashiba, T., and Kobayashi, T. 1996. Rice diseases incited by Rhizoctonia species. In: Rhizoctonia Species: Taxonomy, Molecular Biology, Ecology, Pathology and Disease Control. B. Sneh, S. Jabaji-Hare, S. Neate, and G. Dijst, eds. Kluwer Academic Publishers, Dordrecht, the Netherlands.

Huyse, T., Poulin, R., and Theron, A. 2005. Speciation in parasites: A population genetics approach. Trends Parasitol. 21:469-475.

IBGE. 2006. Censo agropecuário 2006: Brasil, grandes regiões e unidades da federação. IBGE (Instituto Brasileiro de Geografia e Estatística), Rio de Janeiro.

Jia, Y., Correa-Victoria, F., McClung, A., Zhu, L., Liu, G., Wamishe, Y., Xie, J., Marchetti, M., Pinson, S. R. M., Rutger, J. N., and Correll, J. C. 2007. Rapid determination of rice cultivar responses to the sheath blight pathogen Rhizoctonia solani using micro-chamber screening method. Plant Dis. 91:485-489.

Jones, R. K., and Belmar, S. B. 1989. Characterization and pathogenicity of Rhizoctonia spp. isolated from rice, soybean, and other crops grown in rotation with rice in Texas. Plant Dis. 73:1004-1010.

Kamvar, Z. N., Tabima, J. F., and Grunwald, N. J. 2014. Poppr: An R package for genetic analysis of populations with clonal, partially clonal, and/or sexual reproduction. PeerJ 2:e281.

Kelemu, S., Miles, J. W., Bonilla, X. P., and Badel, J. L. 1995. Sources of resistance in species of Brachiaria to foliar blight disease caused by Rhizoctonia solani. Trop. Grassl. 29:257-262.

Ko, W., and Hora, F. 1971. A selective medium for the quantitative determination of Rhizoctonia solani in soil. Phytopathology 61:707-710.

Kohn, L. M. 2005. Mechanisms of fungal speciation. Annu. Rev. Phytopathol. 43:279-308.

Lee, F. N., and Rush, M. C. 1983. Rice sheath blight: a major rice disease. Plant Dis. 67:829-832.

Linde, C. C., Zala, M., Paulraj, R. S. D., McDonald, B. A., and Gnanamanickam, S. S. 2005. Population structure of the rice sheath blight pathogen Rhizoctonia solani AG-1 IA from India. Eur. J. Plant Pathol. 112:113-121.

Mallmann, G., Verzignassi, J. R., Fernandes, C. D., Santos, J. M. d., Vechiato, M. H., Inácio, C. A., Batista, M. V., and Queiroz, C. A. 2013. Fungos e nematoides associados a sementes de forrageiras tropicais. Summa Phytopathol. 39:201-203. 
Marchi, C. E., Fernandes, C. D., Bueno, M. L., Batista, M. V., and Fabris, L. R. 2010. Fungos veiculados por sementes comerciais de braquiária. Arq. Inst. Biol. (Sao Paulo) 77:65-73.

Marchi, C. E., Fernandes, C. D., and Verzignassi, J. R. 2011. Doenças em plantas forrageiras. Documentos. Embrapa Gado de Corte, Campo Grande.

Matsumoto, M. 2002. Trials of direct detection and identification of Rhizoctonia solani AG 1 and AG 2 subgroups using specifically primed PCR analysis. Mycoscience 43:185-189.

Maynard Smith, J., Smith, N. H., O’Rourke, M., and Spratt, B. G. 1993. How clonal are bacteria? Proc. Natl. Acad. Sci. USA 90:4384-4388.

Meirmans, P. G., and Van Tienderen, P. H. 2004. GenoType and GenoDive: Two programs for the analysis of genetic diversity of asexual organisms. Mol. Ecol. Notes 4:792-794.

Ministério da Agricultura Pecuária e Abastecimento-Brasil. 2008. Instrução Normativa no 30, de 21 de maio de 2008. Estabelece normas e padrões para produção e comercialização de sementes de espécies forrageiras de clima tropical, na forma dos Anexos I a VII desta Instrução, que terão validade em todo o território nacional. Diário Oficial da União, Brasília, DF. Secao $\mathrm{I}: 45$.

Mundt, C. C., Sackett, K. E., and Wallace, L. D. 2010. Landscape heterogeneity and disease spread: Experimental approaches with a plant pathogen. Ecol. Appl. 21:321-328.

Nechet, K. L., and Halfeld-Vieira, B. A. 2007. Reação de cultivares de feijãocaupi à mela (Rhizoctonia solani) em Roraima. Fitopatol. Bras. 32:424-428.

Nechet, K. L., Halfeld-Vieira, B. A., Gianluppi, V., and Meyer, M. C. 2008. Reação de cultivares de soja à mela (Thanatephorus cucumeris) em campo em dois estádios de desenvolvimento das plantas. Summa Phytopathol. 34: 277-279.

Ogoshi, A. 1987. Ecology and pathogenicity of anastomosis and intraspecific groups of Rhizoctonia solani Kühn. Annu. Rev. Phytopathol. 25:125-143.

Papaix, J., Adamczyk-Chauvat, K., Bouvier, A., Kiêu, K., Touzeau, S., Lannou, C., and Monod, H. 2014a. Pathogen population dynamics in agricultural landscapes: The Ddal modelling framework. Infect. Genet. Evol. 27:509-520.

Papaïx, J., Touzeau, S., Monod, H., and Lannou, C. 2014b. Can epidemic control be achieved by altering landscape connectivity in agricultural systems? Ecol. Modell. 284:35-47.

Pascual, Toda, Raymondo, and Hyakumachi. 2000. Characterization by conventional techniques and PCR of Rhizoctonia solani isolates causing banded leaf sheath blight in maize. Plant Pathol. 49:108-118.

Prates, R. C., and Bacha, C. J. C. 2011. Os processos de desenvolvimento e desmatamento da Amazônia. Econ. Soc. 20:601-636.

Pritchard, J. K., Stephens, M., and Donnelly, P. 2000. Inference of population structure using multilocus genotype data. Genetics 155:945-959.

Raymond, M., and Rousset, F. 1995. Genepop (Version 1.2): Population genetics software for exact tests and ecumenicism. J. Hered. 86:248-249.

Rosewich, U. L., Pettway, R. E., McDonald, B. A., and Kistler, H. C. 1999. High levels of gene flow and heterozygote excess characterize Rhizoctonia solani AG-1 IA (Thanatephorus cucumeris) from Texas. Fungal Genet. Biol. 28:148-159.

Schuelke, M. 2000. An economic method for the fluorescent labeling of PCR fragments. Nat. Biotechnol. 18:233-234.
Seiffert, N. F. 1984. Gramíneas forrageiras do gênero Brachiaria. EMBRAPA Gado de Corte, Campo Grande.

Silva, E. B. d., Ferreira Júnior, L. G., Anjos, A. F. d., and Miziara, F. 2013. Análise da distribuição espaço-temporal das pastagens cultivadas no bioma Cerrado entre 1970 e 2006. Rev. IDeAS 7:174-209.

Stephens, M., Smith, N. J., and Donnelly, P. 2001. A New statistical method for haplotype reconstruction from population data. Am. J. Hum. Genet. 68:978-989.

Stukenbrock, E. H., and McDonald, B. A. 2008. The origins of plant pathogens in agro-ecosystems. Annu. Rev. Phytopathol. 46:75-100.

Tajima, F. 1989. Statistical method for testing the neutral mutation hypothesis by DNA polymorphism. Genetics 123:585-595.

Tamura, K., Peterson, D., Peterson, N., Stecher, G., Nei, M., and Kumar, S. 2011. MEGA5: Molecular evolutionary genetics analysis using maximum likelihood, evolutionary distance, and maximum parsimony methods. Mol. Biol. Evol. 28:2731-2739.

Thrall, P. H., Oakeshott, J. G., Fitt, G., Southerton, S., Burdon, J. J., Sheppard, A., Russell, R. J., Zalucki, M., Heino, M., and Ford Denison, R. 2011. Evolution in agriculture: The application of evolutionary approaches to the management of biotic interactions in agro-ecosystems. Evol. Appl. 4:200-215.

Torres González, A. M., and Morton, C. M. 2005. Molecular and morphological phylogenetic analysis of Brachiaria and Urochloa (Poaceae). Mol. Phylogenet. Evol. 37:36-44.

Valle, L. C. S., Valério, J. R., Souza, O. C. d., Fernandes, C. D., and Corrêa, E. S. 2000. Diagnóstico de morte de pastagens nas regiões leste e nordeste do estado de Mato Grosso. In Documentos, 97. Campo Grande. Embrapa Gado de Corte. http://old.cnpgc.embrapa.br/publicacoes/doc/doc_pdf/DOC097.pdf

Vechiato, M. H., and Aparecido, C. C. 2008. Fungos em sementes de gramíneas forrageiras: restrição fitossanitária e métodos de detecção. Comunicado Técnico 89. Instituto Biológico, São Paulo.

Verzignassi, J. R., and Fernandes, C. D. 2001. Doenças em forrageiras. In Divulgação Técnica 50. Campo Grande. EMBRAPA Gado de Corte. http://old. cnpgc.embrapa.br/publicacoes/divulga/divulga_pdf/gdcd50PeB.pdf

Watterson, G. A. 1975. On the number of segregating sites in genetical models without recombination. Theor. Popul. Biol. 7:256-276.

Weber, G. F. 1939. Web-blight, a disease of beans caused by Corticium microsclerotia. Phytopathology 29:559-575.

$\mathrm{Xu}$, J. 2005. Cost of interacting with sexual partners in a facultative sexual microbe. Genetics 171:1597-1604.

Yang, X. B., Snow, J. P., and Berggren, G. T. 1989. Morphogenesis of microsclerotia and sasakii-type sclerotia in Rhizoctonia solani, anastomosis group 1, intraspecific groups IA and IB. Mycol. Res. 93:429-434.

Zala, M., McDonald, B. A., Bernardes de Assis, J., Ciampi, M. B., Storari, M., Peyer, P., and Ceresini, P. C. 2008. Highly polymorphic microsatellite loci in the maize- and rice-infecting fungal pathogen Rhizoctonia solani anastomosis group 1 IA. Mol. Ecol. Resour. 8:686-689.

Zhan, J., Pettway, R. E., and McDonald, B. A. 2003. The global genetic structure of the wheat pathogen Mycosphaerella graminicola is characterized by high nuclear diversity, low mitochondrial diversity, regular recombination, and gene flow. Fungal Genet. Biol. 38:286-297.

Zhan, J., Thrall, P. H., and Burdon, J. J. 2014. Achieving sustainable plant disease management through evolutionary principles. Trends Plant Sci. 19: 570-575. 